\title{
Characterization of depositional conditions for lacustrine oil shales in the Eocene Jijuntun Formation, Fushun Basin, NE China
}

\author{
Sheng-Chuan $\mathrm{Xu}^{\mathrm{a}}$ b*, Zhao-Jun Liu ${ }^{\mathrm{b}}$, Pu Zhang ${ }^{\mathrm{a}}$, Jeremy M. Boak ${ }^{\mathrm{c}}$, Rong Liu ${ }^{\mathrm{b}}$, Qing-Tao Meng ${ }^{\mathrm{b}}$ \\ ${ }^{\mathrm{a} C o l l e g e ~ o f ~ R e s o u r c e s, ~ H e b e i ~ G E O ~ U n i v e r s i t y, ~ S h i j i a z h u a n g ~ 050031, ~ C h i n a ~}$

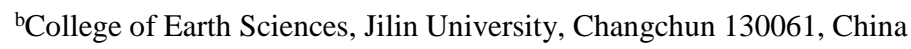 \\ ${ }^{\mathrm{c} C O S T R}$, Colorado School of Mines, Golden, Colorado 80401, USA
}

\section{Abstract}

The strike-slip Fushun Basin hosts a lacustrine oil shale interval of ca. 50-300 $\mathrm{m}$ in the Eocene (Lutetian) Jijuntun Formation. The oil shale deposits consist of the lower lean oil shale unit (LOSU) and the upper rich oil shale unit (ROSU). In outcrop areas, the identified depositional cycles of ca. 8-10 $\mathrm{m}$ and 5-8 $\mathrm{m}$ in thickness record the stacking of massive and non-laminated oil shales in the LOSU and fine- and coarse-laminated oil shales in the ROSU, respectively.

Depositional conditions in the paleo-Jijuntun Lakes were synoptically reconstructed based on sedimentary features, trace element and organic geochemical proxies. Oxic to suboxic, fresh-water conditions were prevailing in the paleo-Jijuntun Lakes during deposition of the LOSU, and then evolved into oxygen-deficient, fresh- to mildly brackish-water conditions during deposition of the ROSU, as revealed by the concentrations of redox- and salinity-sensitive trace elements (e.g. V/Ni, $\mathrm{V} / \mathrm{Cr}, \mathrm{Ni} / \mathrm{Co}$ and $\mathrm{Sr} / \mathrm{Ba}$ ratios, and boron content) in the oil shales. Warm to cool and humid to arid climate (represented by e.g. $\mathrm{Sr} / \mathrm{Cu}$ and $\mathrm{Rb} / \mathrm{Sr}$ ratios) could result in the deepening of water column (from ca. 20-30 $\mathrm{m}$ to ca. $100 \mathrm{~m}$ ) and saline stratification superposed on pre-existing thermal stratification in the paleo-Jijuntun Lakes. A systematical decrease (approximately one order of

*Corresponendce to S.C. Xu, College of Resources, Hebei GEO University, Huai'an east road 136", Shijiazhuang 050031, China. Tel.: +86 15931150846 .

E-mail address: xusc1983@163.com (S.C. Xu). 
magnitude) in the concentrations of most trace elements (except for boron and Co) in the coaly oil shale in the lowermost LOSU, relative to those in the other oil shales in the Jijuntun Formation indicates the significant change of organic matter (OM) input from higher plant (especially coaly materials) to aquatic plankton. This is partly consistent with the variations of OM input from terrestrial higher plant and aquatic organisms (type II kerogen in the LOSU) to lacustrine algae (type I kerogen in the ROSU) as revealed by biomarkers. The slight to significant enrichment or depletion of few trace elements (i.e. Mn and Mo) in these immature to low-mature oil shale deposits may be associated with low to moderate productivities of aquatic plankton and/or incompletely oxygen-free conditions in the paleo-Jijuntun Lakes.

Keywords: Oil shale; Depositional condition; Fushun Basin; Trace element; Organic geochemistry; Jijuntun Lakes.

\section{Introduction}

Tertiary oil shale and lignite are commonly recognized as targets of energy resource exploration (Anadón et al., 1989; Dyni, 2003; Ediger et al., 2014), and as archives of faunal, floral, and climatic evolution (Carroll and Bohacs, 1999; Kraatz and Geisler, 2010; Smith et al., 2008). Previously proposed models for these deposits have remarkably focused on balanced tectonic and climatic controls (e.g. Carroll and Bohacs, 1999, 2001; Sobel and Strecker, 2003; Strecker et al., 2007). However, some studies suggest that the feedback of hydrology and ecology to specific climatic and tectonic conditions has also exerted a well-documented control on organic matter (OM) accumulation, as evident in many Quaternary lakes (Huang et al., 2015; Steinke et al., 2010). Thus, the organic-rich sediments deposited in ancient lakes should 
contain the similar depositional conditions (e.g. OM source, water salinity, and redox state) that have not yet completely defined.

The utility of organic geochemistry (e.g. biomarkers) is widely proposed as a diagnostic record of depositional environment, OM source, and thermal maturity of lacustrine organic-rich facies (e.g. Bechtel et al., 2005; Dawson et al., 2007; Moldowan et al., 1986; Peters and Moldowan, 1993; Seifert and Moldowan, 1986). Similarly, inorganic components (e.g. trace elements) of organic-rich sediments are also employed as an effective indicator of environmental conditions during depositional processes (e.g. Akinlua et al., 2010; Dai et al., 2005; López and Lo Mónaco, 2004; Mongenot et al., 1996). Few studies have documented the detailed relationships of these geochemical proxies (Adegoke et al., 2014; López and Lo Mónaco, 2004; Sarki Yandoka et al., 2015), although an integration of which could provide a fuller understanding of $\mathrm{OM}$ accumulation in modern and/or ancient basin lakes.

The coal- and oil shale-bearing Fushun Basin, representative of several Cenozoic basins around the northern Tanlu Fault and its splaying parts in NE China (Fig. 1a and 1b; Liu et al., 2009), is geologically well described by many published investigations (e.g. Johnson, 1990; Meng et al., 2012; Strobl et al., 2014a, 2014b; Wang et al., 2010; Wu et al., 2002). The Eocene oil shale interval in the Fushun Basin thus offers an opportunity to test hypotheses regarding the origin of lacustrine organic-rich sediments in predominantly siliciclastic lakes (Johnson, 1990), in contrast to those in carbonate-rich lakes (e.g. Green River Formation; Eugster and Surdam, 1973; Roehler, 
1992). This study examines the integration of trace element and organic geochemical proxies from the oil shale deposits, with a goal of better characterizing depositional conditions in the paleo-Jijuntun Lakes of the Fushun Basin. Two principal questions will be also addressed in the present study. First, what conditions are more favorable for OM accumulation? Second, does deposition of the rich oil shales necessarily correspond to warm and humid paleoclimate?

\section{Geologic setting}

\subsection{Structure and tectonics}

The strike-slip Fushun Basin (i.e. Fushun Coalfield; Hong et al., 1980; Johnson, 1990), located at the northern margin of the North China Craton (Fig. 1a), is proximate to the bifurcation point of the Tanlu Fault (Fig. 1b) and was controlled by the Dun-Mi Fault (DMF) during basin evolution (Liu et al., 2009; Wu et al., 2002). The initial strike-slip motion of the Fushun Basin was possibly subject to the end-Triassic left-lateral shearing of the DMF (e.g. Xu and Zhu, 1994), resulting in the fill of the lower Cretaceous. Coeval with the post-Cretaceous pull-apart processes of the DMF (Ren et al., 2002; Zhao et al., 1992), NS- and EW-trending normal faults (e.g. $F_{6}, F_{7}$ and $F_{15} ;$ Fig. 1c) were formed and activated, with significant Tertiary clastic and pyroclastic sediments deposited in the Fushun Basin. Subsequently, the lower Cretaceous was superimposed on the Tertiary induced by ENE- and NW-trending reverse faults (e.g. $F_{1}, F_{1 A}$ and $F_{13}$; Fig. 1c) in the northern Fushun Basin, in response to the Quaternary right-lateral shearing of the DMF ( $\mathrm{Lu}$ et al., 1983). The Fushun Basin appears as a large ENE-trending syncline today (Fig. 1c and 


\subsection{Lithostratigraphy}

Basement rocks in the Fushun Basin consist of a Proterozoic gneiss complex and lower Cretaceous metamorphic conglomerates (Johnson, 1990; Strobl et al., 2014b). The upward Eocene part of the basin fill is assigned as the Laohutai, Lizigou, Guchengzi, Jijuntun and Xilutian formations, respectively (Fig. 1c and Fig. 2; e.g. Huang et al., 1983). The Laohutai and Lizigou formations both consist of alluvial, volcaniclastic sediments and thin coal layers (Wu et al., 2000). The Guchengzi and Jijuntun formations are the main coal- and oil shale-bearing intervals (Johnson, 1990) respectively, containing amounts of floral and faunal fossils (Hong et al., 1980). The overlying Xilutian Formation is totally composed of recurrent mudstones, dolomitic mudstones, and fine-grained sandstones (Huang et al., 1983). All the Eocene stratigraphic packages show conformable contact relationships (Fig. 2 and Fig. 3).

\subsection{Infilling of coal and oil shale deposits}

Identified paludal facies dominates the coal-bearing Guchengzi Formation (Strobl et al., 2014b; Wu et al., 2002; Xu et al., 2012). However, an association of limited fan delta and flood plain facies also sporadically occurs at the base or in marginal areas (Fig. 3). Coal seams, up to 20-200 $\mathrm{m}$ in thickness with an average of ca. $50 \mathrm{~m}$, are occasionally interbedded with shales, mudstones, sandstones and conglomerates (Johnson, 1990; Strobl et al., 2014b; Wu et al., 2002; Xu et al., 2012). The coal deposits appear as a huge lens, gradually splitting and/or thinning toward basin margins (Fig. 3). 
Based on industrial shale oil yields (Dyni, 2003; He, 2004; Liu et al., 2009), the upward Jijuntun Formation is commonly subdivided into the lower lean oil shale unit (LOSU; oil yields <4.7 wt.\%) and the upper rich oil shale unit (ROSU; oil yields $\geq 4.7$ wt.\%), which are approximately $1 / 3$ and $2 / 3$ of the oil shale interval, respectively. All the oil shales were deposited in semi-profundal to profundal environments (Strobl et al., 2014a; Xu et al., 2013), exceptionally rare sublittoral mudstones recorded at the base (Fig. 3 and Fig. 4). The lacustrine Jijuntun Formation ranks among the main oil-shale deposits in the world (Dyni, 2003), and is ca. 50-300 $\mathrm{m}$ in total thickness (Strobl et al., 2014a; Xu et al., 2012).

\section{Materials and methods}

\subsection{Profile and sampling}

Our measured profile is located at an artificial open pit in the western Fushun Basin $\left(41^{\circ} 50^{\prime}-41^{\circ} 51^{\prime} \mathrm{N}, 123^{\circ} 53^{\prime} \mathrm{E}\right.$; Fig. 1c), excavated during coal and oil shale mining. The vertical profile was measured from the uppermost Guchengzi Formation, throughout the Jijuntun Formation, and to the lowermost Xilutian Formation, with intervals of $26.5 \mathrm{~m}, 135.7 \mathrm{~m}$ and $41.8 \mathrm{~m}$, respectively. Twenty-two selected oil shale samples, assigned as nine in the LOSU and thirteen in the ROSU, were taken from the Jijuntun Formation to do further analyses. Each fresh sample, representative of a relatively homogeneous oil shale layer, was labeled in meters from the profile base (Fig. 4).

\subsection{ICP-MS}

Boron, $\mathrm{V}, \mathrm{Ni}, \mathrm{Sr}, \mathrm{Ba}, \mathrm{Cr}, \mathrm{Co}, \mathrm{Cu}, \mathrm{Zn}, \mathrm{Mn}, \mathrm{Mo}, \mathrm{Ga}$ and $\mathrm{Rb}$ (bulk trace elements) 
were analyzed at National Geological Experiment Center of China. Selected samples were ground into $75 \mu \mathrm{m}$ and baked to $700-800{ }^{\circ} \mathrm{C}$ to remove OM. Then, the processed samples were digested in a mixed solution of $\mathrm{HNO}_{3}+\mathrm{HF}$ for a couple of hours. The obtained solutions were measured using a Thermo Scientific Element inductively coupled plasma-mass spectrometer (ICP-MS), with detection limits of ca. $10 \mathrm{ppb}$. Analytical precision was better than 5\%, based on duplicate analyses of samples and standards to calibrate instrument measurement.

\subsection{Isolated kerogen}

Elemental analyses of isolated kerogen were performed at Research Institute of Petroleum Exploration and Development of Petrochina (also for Rock-Eval pyrolysis, hydrocarbon extraction, fractionation and analysis). The crushed oil shale samples $(<0.2 \mathrm{~mm})$ were extracted with a mixture of $\mathrm{CHCl}_{3} / \mathrm{MeOH}(2 / 1, \mathrm{v} / \mathrm{v})$ for $24 \mathrm{hr}$, and isolated kerogens were recovered by the classical $\mathrm{HF} / \mathrm{HCl}$ treatment (Durand and Nicaise, 1980). Then, elements of the kerogen were separated in an Elementar vario ELIII analyzer at $1,050{ }^{\circ} \mathrm{C}$. Finally, $\mathrm{C}, \mathrm{H}, \mathrm{O}, \mathrm{N}$ and $\mathrm{S}$ fractions were determined at $100{ }^{\circ} \mathrm{C}$ by a chromatobar and molecular sieve, respectively.

\subsection{Rock-Eval pyrolysis}

Rock-Eval pyrolysis analyses were performed using a Rock-Eval II analyzer. Firstly, total organic carbon (TOC) content was determined using the standard LECO techniques, after acid treatment to remove carbonates. Then, 50-100 mg pulverized samples were analyzed to obtain $\mathrm{S}_{1}, \mathrm{~S}_{2}, \mathrm{~S}_{3}$, and $T_{\max }$, using the classical Rock-Eval pyrolysis method (Peters, 1986). Finally, amounts of $S_{2}$ and $S_{3}$ pyrolyzate were 
normalized to TOC to record hydrogen index (HI) and oxygen index (OI), respectively. According to TOC and Rock-Eval data, samples were selected for hydrocarbon extraction, fractionation and analysis.

\subsection{Hydrocarbon extraction, fractionation and analysis}

Selected samples were rinsed in dichloromethane to remove organic contaminants and bitumen staining. Then, they were pulverized to $<0.5 \mathrm{~mm}$, and extracted for $24 \mathrm{hr}$ in a Soxtec extractor system using a dichloromethane-methanol mixture (3/1, v/v) to obtain extractable organic matter (EOM). Asphaltenes were precipitated in excess cold pentane and separated by centrifugation. Saturated, aromatic hydrocarbon fractions and NSO compounds were separated by silica gel-alumina chromatography and quantitatively analyzed by a flame ionization detector at $15^{\circ} \mathrm{C}$.

Gas chromatography (GC) of saturated hydrocarbons was performed in a HP-6890 instrument equipped with an OV-1 silica column (30 m length, 0.32 i.d., and $0.3 \mu \mathrm{m}$ film coating). In the vaporizer, the pyrolysis gas was carried by helium flowing at 1.0 $\mathrm{ml} / \mathrm{min}$. The temperature was increased from 80 to $300{ }^{\circ} \mathrm{C}$ at $6{ }^{\circ} \mathrm{C} / \mathrm{min}$. Gas chromatography-mass spectrometry (GC/MS) of the saturated hydrocarbons was performed with an Agilent 5973N spectrometer equipped with a DB-1 silica column (60 m length, 0.25 i.d., and $0.1 \mu \mathrm{m}$ film coating) in detection mode for multiple ions. The relevant biomarkers data were calculated from the peak heights of appropriate mass chromatograms.

\section{Results}

\subsection{Oil shale characterization}


The Jijuntun Formation is bounded by abrupt lithofacies surfaces in outcrop areas (Fig. 5a). Identified depositional cycles with varying thicknesses express as the aggradational stacking of different oil shales in the LOSU and the ROSU, respectively (Fig. 4 and 5a).

Indistinct depositional cycles in the LOSU, ca. 8-10 $\mathrm{m}$ in thickness, consist of three oil shale types with different colors and structures (Fig. 4 and 5b). (i) Massive, medium-gray to gray coaly oil shale with very thin coal layers $(<2 \mathrm{~cm}$; Fig. $5 \mathrm{c})$ only occurs in the lowermost LOSU, and is subsequently absent. (ii) Massive, grayish to gray oil shale with silty lenses and/or intraclasts (Fig. 5d) is widespread at the base of depositional cycles, and is overlain by (iii) macroscopically homogeneous, non-laminated, gray to dark gray oil shale. Floral and faunal fossils are generally absent within the two former oil shales, and are widely present within the latter one (Fig. 5e-5h).

Relatively clear depositional cycles in the ROSU, ca. 5-8 $\mathrm{m}$ in thickness, are recorded by the stacking of strongly laminated oil shale (Fig. 4 and 5i). The laminated oil shale is further subdivided into two types, based on laminae thicknesses appeared in fresh fractures and/or after weathering (Fig. 5j and 5k). (i) Fine-laminated, dark gray oil shale (lamination $<2 \mathrm{~mm}$ ), containing dispersive pyrite grains and fish remains (Fig. 51), is common in the lower to middle intervals of depositional cycles, and is overlain by (ii) coarse-laminated, gray to dark gray oil shale (lamination $\geq 2$ $\mathrm{mm})$, with abundant siderite and few pyrite grains.

\subsection{Trace element concentration}


Bulk trace element concentrations are listed in Table 1 and shown in Fig. 6.

Concentration coefficients (CC; e.g. Dai et al., 2015), i.e. the ratios of trace element concentrations in the studied samples vs. averages in world black shales (Ketris and Yudovich, 2009), are shown in Fig. 7.

The concentrations of most trace elements (except for boron and Co) in the massive coaly oil shale (sample X11-2; Table 1) in the lowermost LOSU are approximately one order of magnitude lower than those in the other oil shales in the Jijuntun Formation. The upward distribution of Mn concentrations (55-3,603 ppm) is characterized by an approximately opposite trend compared with those of $\mathrm{V}$ (5.6-174.6 ppm), Co (10.8-34.1 ppm), Cu (2-49 ppm) and Ga concentrations (1-27 ppm), respectively. Boron and $\mathrm{Sr}$ concentrations are relatively stable in the LOSU (13-45 and 8-296 ppm), but increase near the top of the ROSU (16-95 and 99-686 ppm), respectively (Table 1 and Fig. 6).

Compared with those in worldwide black shales (Ketris and Yudovich, 2009), most lithophile, thiophile and siderophile elements are depleted in the massive coaly oil shale $(\mathrm{CC}<0.5)$ in the lowermost LOSU, with the exception of boron $(\mathrm{CC}=0.8)$ and $\mathrm{Co}(\mathrm{CC}=0.6)$. In contrast, $\mathrm{Mn}(1.0<\mathrm{CC}<9.0)$ and $\mathrm{Mo}(0.02<\mathrm{CC}<0.08)$ are slightly to significantly enriched and depleted in the other oil shales in the Jijuntun Formation respectively, while the rest of the studied trace elements approximately fall in normal areas (Fig. 7).

$\mathrm{V} / \mathrm{Ni}(0.8-3.6)$ and $\mathrm{V} / \mathrm{Cr}$ ratios $(0.7-1.5)$ have approximately similar distributions. The values of $\mathrm{V} /(\mathrm{V}+\mathrm{Ni}),(\mathrm{Cu}+\mathrm{Mo}) / \mathrm{Zn}$ and $\mathrm{Ga} / \mathrm{Rb}$ ratios span narrow ranges of 
$0.4-0.8,0.1-0.6$ and $0.2-0.4$, respectively. The values of $\mathrm{Ni} / \mathrm{Co}$ ratios increase from 0.6 to 4.5. The distributions of $\mathrm{Sr} / \mathrm{Ba}(0.1-1.6)$ and $\mathrm{Sr} / \mathrm{Cu}$ ratios (1.5-23.2) are both comparable to that of element $\mathrm{Sr}$. The distribution of $\mathrm{Rb} / \mathrm{Sr}$ ratios $(0.1-1.1)$ is featured by a decreasing trend (Table 1 and Fig. 6).

\subsection{Bulk geochemical composition}

Isolated kerogen elements and Rock-Eval pyrolysis parameters are listed in Table 2 and shown in Fig. 8. Identified kerogen types are summarized in Fig. 9.

\subsubsection{Elemental analyses of isolated kerogen}

The average amounts of element $\mathrm{C}$ and $\mathrm{N}$ in the LOSU (60.6\% and 2.2\%) are subequal to those in the ROSU (60.8\% and $2.2 \%)$, with values of $\mathrm{C} / \mathrm{N}$ ratios in ranges of 21-39 and 21-37, respectively (Table 2 and Fig. 8a). In contrast, opposite distributions are present between $\mathrm{H}$ and $\mathrm{O}$. The elevated amounts of $\mathrm{S}$ result in the decreasing mean values of C/S ratios from 17 to 7 (Table 2 and Fig. 8b). Atomic H/C and $\mathrm{O} / \mathrm{C}$ ratios fall in the areas of type III-II and II-I kerogens, respectively (Table 2 and Fig. 9a).

\subsubsection{Rock-Eval pyrolysis parameters}

The values of TOC contents, except for $30.27 \mathrm{wt} . \%$ at the profile base (sample X11-2; see Table 1 for lithology), increase from the LOSU (2.25-6.16 wt.\%) to the ROSU (5.36-18.81 wt.\%; Table 2 and Fig. 8c). $T_{\max }$ values span an increasing range of $429-446{ }^{\circ} \mathrm{C}$ throughout the Jijuntun Formation (Table 2 and Fig. 8d). The distribution of $S_{2}$ is approximately similar to that of TOC contents (Fig. 8e), resulting in elevated HI values of 212-656 mg HC/g TOC (Table 2 and Fig. 8f). The OM types, 
as shown in Fig. 9b, are further defined as a predominant type II kerogen for the LOSU and a type I kerogen for the ROSU based on true HI values of 394 and $635 \mathrm{mg}$ HC/g TOC, respectively (Fig. 9c; Langford and Blanc-Valleron, 1990).

\subsection{Hydrocarbon extraction}

The values of EOM contents vary from $4-36 \mathrm{mg} / \mathrm{g}$ TOC to $16-84 \mathrm{mg} / \mathrm{g}$ TOC through the Jijuntun Formation (Table 2). The contents of saturated and aromatic hydrocarbons are characterized by opposite distributions, with mean values of $16 \%$ and $29 \%$ in the LOSU and $36 \%$ and $15 \%$ in the ROSU, respectively. The contents of NSO compounds decrease from $64 \%$ to $33 \%$. In contrast, the proportion of asphaltenes is low in both units (3-16\%; Table 2 and Fig. 8g).

\subsection{Biomarker compounds}

Total ion chromatograms (TICs) of saturated hydrocarbons are shown in Fig. 10. $m / z, 191$ and $m / z 217$ chromatograms and identified peaks are shown in Fig. 11 and listed in Table 3, respectively. Biomarkers are listed in Table 4 and shown in Fig. 12.

\subsubsection{Acyclic alkanes}

All $n$-alkanes, consisting of major intermediate to long chain $\left(\mathrm{C}_{22}-\mathrm{C}_{45}\right) n$-alkanes and minor short chain $\left(\mathrm{C}_{10}-\mathrm{C}_{21}\right)$ ones, are characterized by similar bimodal distributions (Fig. 10). The values of carbon preference index (CPI; Bray and Evans, 1961) and odd-even preference (OEP; Scalan and Smith, 1970) vary in ranges of $1.16-1.90$ and $1.61-2.42$, respectively (Table 4).

Acyclic isoprenoids pristane $(\mathrm{Pr})$ and phytane $(\mathrm{Ph})$ both occur in significant amounts (Fig. 10), with high values of $\mathrm{Pr} / \mathrm{Ph}$ ratios (1.46-4.51), varying values of 
$\mathrm{Pr} / n-\mathrm{C}_{17}(0.82-18.21)$ and $\mathrm{Ph} / n-\mathrm{C}_{18}$ ratios (0.53-8.00), respectively (Table 4 and Fig. 12a-12c). Trace amounts of $\beta$-carotane (1.37 $\mu \mathrm{g} / \mathrm{g}$ TOC) are present in a single oil shale extract from the uppermost Jijuntun Formation (sample X78-1; Fig. 10 and Table 4), consistent with organic input from specific algae and/or bacteria (Hall and Douglas, 1983; Koopmans et al., 1997; Murphy et al., 1967).

\subsubsection{Polycyclic Terpanes}

The contents of sesquiterpenoids and diterpenoids are both high in the lowermost Jijuntun Formation (up to 213 and $376 \mu \mathrm{g} / \mathrm{g}$ TOC), but obviously decrease upward (Fig. 10 and Table 4). Triterpenoids, characterized by major $\mathrm{C}_{19}-\mathrm{C}_{21}$ and minor $\mathrm{C}_{22}-\mathrm{C}_{26}$ tricyclic terpanes, are present in relatively stable quantities (11-40 $\mu \mathrm{g} / \mathrm{g}$ TOC; Fig. 11a and Table 4). In addition, $\mathrm{C}_{24}$ tetracyclic terpane was detected in low contents (Fig. 11a, Table 3 and 4).

Abundant hopanes (100-866 $\mu \mathrm{g} / \mathrm{g}$ TOC) are dominated by $\mathrm{C}_{29}$ norhopane and $\mathrm{C}_{30}$ hopane (Fig. 11a and Table 4). 17 $\alpha(\mathrm{H})$-22,29,30-trisnorhopane (Tm) predominates over $18 \alpha(\mathrm{H})-22,29,30$-trisnorneohopane (Ts), resulting in low values of Ts/Tm ratios of $0.05-0.43$. The distribution of homohopanes is characterized by a predominance of $\mathrm{C}_{31}$ homohopane, with values of uniform $22 \mathrm{~S} /(22 \mathrm{~S}+22 \mathrm{R})$ ratios of $0.43-0.59$. The upward distribution of low abundances of gammacerane $(0.12-1.75 \mu \mathrm{g} / \mathrm{g}$ TOC; Fig. 11a and Table 4) is featured by an increasing trend similar to those of gammacerane index (0.004-0.021) and triterpenoids index (0.61-1.23; Table 4, Fig. 12d and 12e).

\subsubsection{Steroids}

Steranes, dominated by regular steranes, diasteranes and $\mathrm{C}_{22}$ homopregnane, are 
present in low abundances (8-97 $\mu \mathrm{g} / \mathrm{g}$ TOC) relative to hopanes (Fig. 11b, Table 3 and 4). Among the regular steranes, $C_{29}$ sterane is generally greater than $C_{27}$ and $C_{28}$ steranes, whereas $\mathrm{C}_{27}$ sterane is subequal to or slightly greater than $\mathrm{C}_{28}$ sterane in quantities (Table 4), with values of $\mathrm{C}_{29} / \mathrm{C}_{27}$ steranes ratios of 1.14-2.69 (Fig. 12f). Diasteranes and regular steranes have the similar carbon-number distributions (Fig. $11 \mathrm{~b}$ and Table 3), characterized by declining distributional trends of diasterane index (Fig. 12g) and isomerization ratios of $20 \mathrm{~S} /(20 \mathrm{~S}+20 \mathrm{R})$ and $\beta \beta /(\beta \beta+\alpha \alpha)$, respectively

(Table 4). Furthermore, the values of hopanoid/steroid ratios decrease upward from 21.68 to 6.56 (Table 4 and Fig. $12 \mathrm{~h}$ ).

\section{Discussion}

\subsection{Redox conditions}

\subsubsection{Trace element parameters}

The concentrations of $\mathrm{V}$ and $\mathrm{Ni}$ in organic-rich sediments are sensitive to redox conditions of water column, as evident in different sedimentary settings (Akinlua et al., 2010; López et al., 1995; López and Lo Mónaco, 2004; Mongenot et al., 1996; Shi et al., 2015). Generally, the values of V/Ni ratios of >3.0 and 1.9-3.0 suggest reducing and suboxic conditions, respectively (Galarraga et al., 2008; Lewan and Maynard, 1982; Lewan, 1984; Quinby-Hunt and Wilde, 1994). Similarly, the values of $\mathrm{V} /(\mathrm{V}+\mathrm{Ni})$ ratios of $>0.84,0.54-0.82$, and $0.46-0.60$ are indicative of euxinic, anoxic, and dysoxic conditions, respectively (e.g. Hatch and Leventhal, 1992; Shi et al., 2015). Vanadium vs. Ni concentrations in the oil shale deposits shows that the LOSU is widely scattered in terrestrial oxic to marine anoxic areas, whereas the 
ROSU is tightly around a marine-terrestrial oxic-dysoxic zone (Fig. 13a). The V/Ni and $\mathrm{V} /(\mathrm{V}+\mathrm{Ni}$ ) ratios in the LOSU (avg. 2.3 and 0.7) and the ROSU (avg. 2.0 and 0.7) are both representative of suboxic to dysoxic conditions (Table 1 and Fig. 6).

Therefore, an alternation of suboxic-oxic to oxic environments was prevailing during deposition of the Jijuntun Formation.

$\mathrm{V} / \mathrm{Cr}, \mathrm{Ni} / \mathrm{Co}$ and $(\mathrm{Cu}+\mathrm{Mo}) / \mathrm{Zn}$ ratios are also used to determine the depositional environment of organic-rich sediments (e.g. Akinlua et al., 2010; Jones and Manning, 1994; Mohialdeen and Raza, 2013). The values of V/Cr, Ni/Co and $(\mathrm{Cu}+\mathrm{Mo}) / \mathrm{Zn}$ ratios in the oil shale deposits are less than 2.0, 5.0 and 1.0 respectively (Table 1 and Fig. 6), consistently suggesting a suboxic-oxic depositional environment for the Jijuntun Formation. In addition, all the oil shale samples subdivide into two distinct populations in the plot of V/Cr vs. Ni/Co ratios (Fig. 13b), further implying that the ROSU was likely deposited in a more reducing environment compared with the

\section{LOSU.}

\subsubsection{Biomarkers}

The values of $\mathrm{Pr} / \mathrm{Ph}$ ratios of $>3.0,1.0-3.0$ and $<1.0$ represent oxic conditions with terrigenous $\mathrm{OM}$ input, dysoxic and anoxic conditions during early diagenesis, respectively (Bechtel et al., 2005; Powell, 1988; ten Haven et al., 1987; Waseda and Nishita, 1998; Zakir Hossain et al., 2009). Although influenced by OM types (see Section 5.2.), the $\mathrm{Pr} / \mathrm{Ph}$ ratios in the LOSU (2.91-4.51) and the ROSU (1.46-2.08) are preliminarily indicative of dysoxic-oxic and dysoxic environments (c.f. Strobl et al., 2014a, 2014b), respectively (Table 4 and Fig. 12a). This is consistent with similar 
redox conditions inferred from Ts/Tm ratios (Table 4; e.g. Peters and Moldowan, 1993; Zakir Hossain et al., 2009). In addition, the plot of $\mathrm{Pr} / \mathrm{Ph}$ vs. regular steranes $\mathrm{C}_{27} /\left(\mathrm{C}_{27}+\mathrm{C}_{29}\right)$ ratios shows that environmental conditions were terrestrial oxic and then terrestrial suboxic to anoxic during deposition of the LOSU and the ROSU, respectively (Fig. 13c; e.g. Waseda and Nishita, 1998; Zakir Hossain et al., 2009).

Although affected by biodegradation and maturity (e.g. ten Haven et al., 1987), some authors debated that the $\mathrm{Pr} / n-\mathrm{C}_{17}$ and $\mathrm{Ph} / n-\mathrm{C}_{18}$ alkanes ratios of deposited $\mathrm{OM}$ are also associated with environmental conditions (e.g. Amijaya et al., 2006; Sarki Yandoka et al., 2015; Zakir Hossain et al., 2009). In the present study, the significant variations of these ratios cannot be ascribed to different thermal maturities, as an immature to low-mature thermal level is common in the Jijuntun Formation (see Section 5.6.1.; e.g. George et al., 2001; Tissot and Welte, 1984). Moreover, a very limited degree of biodegradation in deposited OM is consistent with EOM compositions (Table 2 and Fig. 8g) and low unresolved complex mixture contents (Fig. 10) in the oil shale extracts. Therefore, the variations of $\mathrm{Pr} / n-\mathrm{C}_{17}$ and $\mathrm{Ph} / n-\mathrm{C}_{18}$ alkanes ratios (Table 4, Fig. 12b and 12c) relate to oxic and reducing conditions with different OM input for the LOSU and the ROSU, respectively (Fig. 13d).

\subsection{Organic matter source}

Long chain $n$-alkanes (e.g. $\mathrm{C}_{20}-\mathrm{C}_{35}$ ) are derived from terrestrial higher plant waxes and cuticles, while short chain ones (e.g. $\mathrm{C}_{12}-\mathrm{C}_{18}$ ) are typical of OM input from algae and phytoplankton cell membranes (Meyers, 1997; Tegelaar et al., 1989; Tissot and Welte, 1984). Similar bimodal $n$-alkanes distributions in all the oil shale 
extracts may imply that the OM input from terrestrial higher plant is subequal to or exceed that from lacustrine algae and/or plankton (Fig. 10 and Table 4).

It has been accepted that $\mathrm{Pr}$ and $\mathrm{Ph}$ are mainly derived from chlorophylls of algae and cyanobacteria (Dawson et al., 2007), although some proposed specific precursors are likely (e.g. archaebacteria and tocopherols; Bechtel et al., 2005, 2007; Goossens et al., 1984). The high values of $\mathrm{Pr} / \mathrm{Ph}$ ratios in the LOSU may result from a significant contribution of terrigenous and aquatic organisms, while those in the ROSU could relate to increasing algae input (Table 4, Fig. 12a and 13c), consistent with results of $\mathrm{Pr} / n-\mathrm{C}_{17}$ vs. $\mathrm{Ph} / n-\mathrm{C}_{18}$ alkanes ratios (Fig. $13 \mathrm{~d}$ ).

$\mathrm{C}_{27}$ and $\mathrm{C}_{28}$ steranes are generally originated from (specific) phytoplankton and/or algae, whereas $\mathrm{C}_{29}$ sterane is representative of $\mathrm{OM}$ input from terrestrial higher plant (Huang and Meinschein, 1979; Moldowan et al., 1986; Volkman, 2003). As shown in Fig. 13e, the distributions of regular steranes in the ROSU (mean $\mathrm{C}_{29}>\mathrm{C}_{27}>\mathrm{C}_{28}$ ) are suggestive of increasing aquatic organisms and decreasing terrestrial land plant materials compared with those in the LOSU (mean $\mathrm{C}_{29} \gg \mathrm{C}_{28} \geq \mathrm{C}_{27}$; Table 4 and Fig. 12f). The variations of OM input are further confirmed by the upward decreases of sesquiterpenoids and diterpenoids contents and increase of triterpenoids index throughout the Jijuntun Formation, and trace amounts of $\beta$-carotane occurred near the top of the ROSU, respectively (Fig 10 and Table 4; e.g. Carroll and Bohacs, 2001; Hall and Douglas, 1983; Moldowan et al., 1986).

Low abundances of gammacerane in all the oil shale extracts (Fig. 11a) imply the minor organic input from bacterivores (e.g. ciliates) living at or below the chemocline 
in stratified lakes (Moldowan et al., 1986; Sinninghe Damsté et al., 1995). The medium to high values of hopanoid/steroid ratios (Table 4 and Fig. 12h) indicate the organic input from special bacteria for the oil shale deposits (e.g. cyanobacteria; Bechtel et al., 2005), consistent with the significant enrichment of isotopic $\delta^{13} \mathrm{C}$ in specific compounds (e.g. phytol) induced by bacterial activities in the Fushun Basin (Strobl et al., 2014a, 2014b).

\subsection{Salinity, stratification, and depth of the Jijuntun Lakes}

\subsubsection{Salinity of the Jijuntun Lakes}

Although in debate, it is proposed that boron concentrations of organic-rich sediments of $<50 \mathrm{ppm}, 50-110 \mathrm{ppm}$, and $>110 \mathrm{ppm}$ represent freshwater, mildly brackish-water, and brackish-water conditions, respectively (e.g. Banerjee and Goodarzi, 1990; Dai et al., 2005, 2006; Goodarzi and Swaine, 1994). The concentrations of boron in the LOSU (13-45 ppm, avg. $24 \mathrm{ppm}$ ) and the ROSU (16-95 ppm, avg. 38 ppm) thus consistently indicate that the Jijuntun Lakes were primarily dominated by freshwater conditions and/or were influenced by mildly brackish-water conditions during deposition of the oil shales (Table 1 and Fig. 6). Furthermore, higher values of $\mathrm{Sr} / \mathrm{Ba}$ ratios preserved in fine-grained sediments are empirically associated with saline-water conditions in basin lakes and vice versa (Deng and Qian, 1993; Fu et al., 2011). A low salinity level occurred in the Jijuntun Lakes is also attested by the $\mathrm{Sr} / \mathrm{Ba}$ ratios in the $\operatorname{LOSU}(0.1-0.6$, avg. 0.2) and the ROSU (0.2-1.6, avg. 0.5), respectively (Table 1 and Fig. 6). However, the sudden increase in values of $\mathrm{Sr} / \mathrm{Ba}$ ratios near the top of the ROSU may argue that water 
column of the Jijuntun Lakes was occasionally mildly brackish during the end-Lutetian period (Fig. 6 and 13f).

Strobl et al. (2014a) proposed that $\mathrm{C} / \mathrm{S}$ ratios in the Fushun Basin reflect a freshwater environment in spite of those values around and less than 10 in the upper or uppermost Jijuntun Formation. However, Berner and Raiswell (1984) reported that the values of $\mathrm{C} / \mathrm{S}$ ratios of $0.5-5$ and $>10$ are diagnostic of marine mudstones and freshwater rocks, respectively. In this study, the values of $\mathrm{C} / \mathrm{S}$ ratios of isolated kerogens vary from 11-30 (avg. 17) in the LOSU to 5-11 (avg. 7) in the ROSU (Table 2 and Fig. 8b). Alternatively, we infer that the LOSU was deposited under freshwater conditions, whereas the ROSU was significantly influenced by mildly brackish water rather than freshwater (c.f. Strobl et al., 2014a, 2014b).

Greater abundances of gammacerane and higher values of gammacerane index are often associated with hypersaline conditions in water column (Mello et al., 1988; Peters and Moldowan, 1993; Sinninghe Damsté et al., 1995). Based on comparison with data of other lacustrine sediments (Mello et al., 1988), the predominance of a low salinity level in the Jijuntun Lakes is also confirmed by low gammacerane contents and gammacerane index values from all the oil shale extracts (Table 4 and Fig. 12d). In addition, the mildly brackish-water conditions, recorded in the upper and/or uppermost ROSU (Fig. 13f and 13g), are consistent with widespread dolomitic layers in the overlying Xilutian Formation (Huang et al., 1983).

\subsubsection{Stratification of the Jijuntun Lakes}

Few benthic fossils (e.g. gastropods; Fig 4 and Fig. 5h) observed in the LOSU 
argue that water column in the Jijuntun Lakes may be occasionally well oxygenated during the early Lutetian period. As inferred from trace element parameters (Table 1, Fig. 6, Fig. 13a and 13b) and biomarkers (Table 4, Fig. 13c and 13d), relatively oxic environmental conditions were prevailing during this stage. A low level of salinity in water column may be unfavorable to maintain long-standing stratification during deposition of the LOSU (Fig. 13f and 13g). In most modern tropic lakes, the water stratification induced by temperature rather than salinity is prone to experiencing semi-annual and/or annual overturn (Katz, 1990; Walker, 2011). Therefore, the episodic holomixis could result in (sub)oxic conditions in the Jijuntun Lakes to support bottom-dwelling activities during deposition of the LOSU.

In contrast, absent benthos and abundant fish fossils (Fig 4 and Fig. 51) preserved in the ROSU are representative of well-developed stratified water column (Katz, 1990; Olsen, 1990). Therefore, the Jijuntun Lakes were at least characterized by meromictic conditions during deposition of the ROSU. A predominantly anoxic environment was prevailing in water column under the redoxcline, as revealed by trace element parameters (Table 1, Fig. 6, Fig. 13a and 13b) and biomarkers (Table 4, Fig. 13c and 13d). In addition, the significant influences of mildly brackish-water conditions (Fig. $13 \mathrm{f}$ and $13 \mathrm{~g}$ ) subsequently enhanced the stratification of water column in the Jijuntun Lakes and resulted in oxygen depletion during deposition of the ROSU.

\subsubsection{Depth of the Jijuntun Lakes}

The maximum depth of water column in the paleo-Jijuntun Lakes is unclear, but it can reach up to dozens of meters based on the extent of the deposited oil shales (Fig. 
$1 \mathrm{c}$ and 5a). Similarly, the minimum depth of water column for deposition of the oil shale deposits is also unknown. It is argued that the water depth for deposition of micro-laminated sediments is greater than storm wave base (Duncan and Hamilton, 1988), which is depended on wind fetch from the areal extent of the lake deposits and various wind speeds (Olsen, 1990). The oil shale deposits in the Fushun Basin span an approximate distance of $>20 \mathrm{~km}$ along its long axis (Fig. 1c; Johnson, 1990; Liu et al., 2009). According to the correlations of the depth of wave base vs. wind fetch as proposed by Olsen (1990), the maximum depth of the paleo-Jijuntun Lakes is roughly estimated as ca. $100 \mathrm{~m}$. This is consistent with the tectonic subsidence rates of the Fushun Basin (Wu et al., 2002) and survival domains of specific ostracods preserved in the lowermost Xilutian Formation (e.g. Hemicyprinotus cf. reniformis and Limnocythere sp. nov.; Hong et al., 1980). Furthermore, the close vertical association of mudstones with ripple bedding and/or silty lenses (Fig. 5d) within sublittoral facies (Fig. 3) suggests that the LOSU were approximately deposited in water column of ca. 20-30 $\mathrm{m}$ in depth, consistent with the drowning processes of pre-existing mires in the Guchengzi Formation (Liu et al., 2009; Wu et al., 2000).

\subsection{Paleoclimate control on deposition of oil shales}

Zhao et al. (1992) placed the Eocene Fushun Basin on a moderate paleolatitude $\left(38.1^{\circ}\right.$ north) based on geomagnetic data, where the early Eocene greenhouse paleoclimate was similar to those in coeval Mediterranean and North America (Utescher and Mosbrugger, 2007; Zachos et al., 2001). As inferred from pollen assemblages and floral remains, high mean annual temperature and precipitation were 
prevailing during deposition of the Jijuntun Formation (Hong et al., 1980; Wang et al., 2010).

Generally, $\mathrm{Sr} / \mathrm{Cu}, \mathrm{Ga} / \mathrm{Rb}$ and $\mathrm{Rb} / \mathrm{Sr}$ ratios of fine-grained sediments are sensitive to climatic variations during depositional processes (e.g. Beckmann et al., 2005). The values of $\mathrm{Sr} / \mathrm{Cu}$ ratios of $1.3-5.0$ and $>5.0$ are associated with humidity and aridity, respectively (Adegoke et al., 2014; Sarki Yandoka et al., 2015). In addition, the values of $\mathrm{Ga} / \mathrm{Rb}$ and $\mathrm{Rb} / \mathrm{Sr}$ ratios both decline with increasing aridity and decreasing temperature (Deng and Qian, 1993; Roy and Roser, 2013). The relatively uniform $\mathrm{Ga} / \mathrm{Rb}$ ratios in the LOSU (0.2-0.5) and the ROSU (0.3-0.4) both imply that the Fushun Basin was characterized by moderate warm/humid climate during deposition of the Jijuntun Formation (Table 1 and Fig. 13h). However, a sudden increase in values of $\mathrm{Sr} / \mathrm{Cu}$ ratios occurred in the upper or uppermost ROSU likely argues for a transition of warm/humid to cool/arid climate (Fig. 13h; c.f. Meng et al., 2012; Strobl et al., 2014a), consistent with the upward decrease in values of $\mathrm{Rb} / \mathrm{Sr}$ ratios (Table 1 and Fig. 6).

During deposition of the LOSU (early Lutetian), warm/humid climate (Fig. 13h) was in favor of flourishing higher plant around the paleo-Jijuntun Lakes (Fig. 5e-5g), supplying significant terrigenous OM input for the oil shale deposits (Strobl et al., 2014a; Xu et al., 2012). The relatively high temperature could result in unstable thermal stratification of water column, which was well oxygenated during annual overturn processes (Katz, 1990; Walker, 2011). The high rainfall may maintain the Jijuntun Lakes under a freshwater condition (Fig. 13f and 13g) and cause deposition 
of the massive and non-laminated oil shales (Fig. 5c-5h) with substantial terrestrial minerals (Liu et al., 2015; Meng et al., 2012). The periodic influx of clastic sediments induced by high rainfall (Liu et al., 2009; Xu et al., 2012), partly documented as widespread silty lenses within the massive oil shales (Fig. 5d), could result in thick deposition cycles in the LOSU (Fig 5a and 5b).

In contrast, warm/humid to cool/arid climate (Fig. 13h) was prevailing during deposition of the ROSU (late Lutetian). The decreasing rainfall and moderate aridity perhaps induced fresh- to mildly brackish-water conditions in the paleo-Jijuntun Lakes, superposing saline stratification on pre-existing thermal stratification (Moldowan et al., 1986; Sinninghe Damsté et al., 1995). The deepening of the Jijuntun Lakes was favorable for deposition of the strongly laminated oil shales (Fig. $5 \mathrm{j}$ and $5 \mathrm{k}$ ) with increasing aquatic organic input under oxygen-deficient environmental conditions. In addition, transported clastic materials were prone to minimums, as revealed by absent basin margin facies in the ROSU (Fig. 3; Liu et al., 2009; Xu et al., 2012). Consequently, distinctly expressed depositional cycles in the ROSU are thin relative to those in the LOSU (Fig 5a and 5i).

\subsection{Controls on trace element enrichment}

Unusually high productivities, associated with significant enrichments of trace elements in the oil shale deposits, might unlikely occur owing to absent nutrients around the paleo-Jijuntun Lakes (e.g. phosphate-rich rocks; Hyacinthe and Van Cappellen, 2004). In contrast, the low values of $\mathrm{C} / \mathrm{N}$ ratios of isolated kerogens (Table 2 and Fig. 8a) suggest low to moderate productivities of biomass (e.g. Meyers, 1997). 
Similarly, the variations of trace element concentrations in the oil shale deposits cannot be attributed to different terrestrial clastic compositions, since the pre-Jijutun Formation rocks in and/or around the Fushun Basin are regarded as a unique potential provenance (Fig. 1c; e.g. Liu et al., 2009; Xu et al., 2012). As a result, the possible influences from OM and diagenesis are discussed in the present study.

Clay minerals in the oil shale deposits are dominated by kaolinite, illite and smectite (Meng et al., 2012; Strobl et al., 2014a), suggesting late-early to early-middle diagenetic stages of the Jijuntun Formation (e.g. Foscolos et al., 1976). This is also consistent with the sub-bituminous to volatile bituminous ranks of coal seams in the underlying Guchengzi Formation (Strobl et al., 2014b; Wu et al., 2002). Considering the absence of abnormal heat flow (Wu et al., 2002), all the oil shale deposits should undergo similar degrees of diagenesis during the Oligocene through Holocene.

Varying concentrations of studied trace elements between the massive coaly oil shale and the other oil shales in the Jijuntun Formation (Table 1 and Fig. 7) somewhat mirror the differential accumulation of trace elements between worldwide coals and black shales (Ketris and Yudovich, 2009). It is proposed that some trace elements (e.g. $\mathrm{Ni}, \mathrm{Cd}, \mathrm{Cu}, \mathrm{Zn}$ and $\mathrm{Mo}$ ), serving as micronutrients in aquatic ecosystems, are adsorbed onto sediment particles and/or buried into sediments by the biotic activities of plankton (mainly phytoplankton) rather than terrigenous higher plant (e.g. Calvert and Pederson, 1993; Morel and Price, 2003; Tribovillard et al., 2006). As observed in outcrop areas, coaly materials are common and locally form thin coal layers within the massive coaly oil shale in the lowermost LOSU (Fig. 5c). In addition, pyrite and 
siderite grains scattered within the oil shale deposits (e.g. Strobl et al., 2014a; Xu et al., 2012) imply that sulfide mineral phases could occur in the paleo-Jijuntun Lake. Thus, the systematical depletion of trace elements in the coaly oil shale in the lowermost LOSU, except for boron and Co (Table 1 and Fig. 7), is closely associated with the significant contribution of coaly materials, rather than the reductive dissolution of Fe- and/or Mn-(oxyhydr)oxides with releases of trace elements to the anoxic zone (e.g. Repeta, 1993). The normal enrichment of boron and Co, relative to other studied trace elements (Table 1 and Fig. 7), is likely relate to insoluble sulfide precipitates (e.g. pyrite; Huerta-Diaz and Morse, 1990) in the coaly oil shale in the lowermost ROSU.

Compared with those in worldwide black shales (Ketris and Yudovich, 2009), most of the normally enriched trace elements (except for Mn and Mo; Table 1 and Fig. 7) in the other oil shales in the Jijuntun Formation are representative of low to moderate productivities and aquatic OM influx. The negative correlations of $\mathrm{Mn}$ concentrations with both TOC and HI values in the other oil shales in the Jijuntun Formation (Fig. 14a and 14b) imply the absence of immobile Mn completely binding to deposited OM in the paleo-Jijuntun Lakes. In reducing soft sediments, mobile $\mathrm{Mn}^{2+}$, geochemically similar to $\mathrm{Fe}^{2+}$, might be incorporated into the particulate sulfates instead of Mn-(oxyhydr)oxides, owing to bacterial reduction of sulfates (e.g. Huerta-Diaz and Morse, 1990; Morel and Price, 2003). The slight to significant enrichment of Mn (Table 1 and Fig. 7) in the other oil shales in the Jijuntun Formation could result from moderate insoluble sulfide precipitates. In contrast, the 
positive correlations of Mo concentrations with both TOC and HI values in the other oil shales in the Jijuntun Formation (Fig. 14c and 14d) show that the preservation of Mo is closely associated with the variations in aquatic organic influx (Calvert and Pederson, 1993; Morel and Price, 2003; Tribovillard et al., 2006). In addition, the mobile oxyanions of Mo are reduced by sulfides and incorporated into particulate pyrites, which requires strongly anoxic conditions (e.g. high degrees of pyritization) relative to other studied elements (Audry et al., 2006; Morel and Price, 2003). The significant depletion of Mo in the other oil shales in the Jijuntun Formation thus results from either low to moderate productivities and/or suboxic-anoxic conditions in the paleo-Jijuntun Lakes.

\subsection{Thermal maturity and hydrocarbon potential}

\subsubsection{Thermal maturity of oil shales}

In this study, no vitrinite reflectance was measured owing to the prevalence of very small vitrinite particles (Strobl et al., 2014a). However, few data show that the oil shale deposits in the Jijuntun Formation underwent a low level of thermal maturity $\left(R_{\mathrm{O}}=0.43-0.56 \%\right.$; Liu et al., 2009), consistent with evidences from coal seams in the underlying Guchengzi Formation $\left(R_{\mathrm{o}}=0.40-0.85 \%\right.$; Huang et al., 1983; Wu et al., 2000).

The values of CPI and OEP greater than 1.16 and 1.61 (Table 4) suggest that the oil shale deposits are immature to low-mature (Bray and Evans, 1961; Peters, 1986; Peters and Moldowan, 1993). $T_{\max }$ values decrease from $440-446^{\circ} \mathrm{C}$ (in the ROSU) to 429-438 ${ }^{\circ} \mathrm{C}$ (in the LOSU) with increasing burial depth (Table 2 and Fig. 8d), 
indicating that $T_{\max }$ values of the oil shale deposits are strongly influenced by kerogen types rather than different levels of thermal maturity (Peters, 1986). Based on identified OM types (Fig. 9), type I kerogen should have higher $T_{\max }$ values than type II kerogen in the oil shale deposits attaining insufficient thermal maturity (e.g. Strobl et al., 2014a). The increasing values of $22 \mathrm{~S} /(22 \mathrm{~S}+22 \mathrm{R})$ homohopane ratios are less than 0.6 and also indicate an immature to low-mature thermal level (George et al., 2001; Seifert and Moldowan, 1986), consistent with evidences from sterane isomerization ratios of $20 \mathrm{~S} /(20 \mathrm{~S}+20 \mathrm{R})$ and $\beta \beta /(\beta \beta+\alpha \alpha)$ (Table 4).

\subsubsection{Hydrocarbon potential of oil shales}

Pyrolytic $S_{1}$ and $S_{2}$ from Rock-Eval parameters are used to identify hydrocarbon potential of source rocks (Tissot and Welte, 1984). The values of generative potential $\left(\mathrm{S}_{1}+\mathrm{S}_{2}\right)$ in the LOSU (avg. $27.1 \mathrm{mg} \mathrm{HC} / \mathrm{g}$ ) are lower than those in the ROSU (avg. $74.6 \mathrm{mg} \mathrm{HC} / \mathrm{g}$ ). Since the oil shale deposits are classified as immaturity to low maturity, the values of pyrolytic $S_{1}$ and $S_{2}$ yields can signal primary hydrocarbon potential of the Jijuntun Formation significantly influenced by different kerogen types (Fig. 9). According to Tissot and Welte (1984), the oil shale deposits in the LOSU and the ROSU fall in the good and very good areas for source rocks respectively, consistent with the variations of EOM compositions (Table 2 and Fig. 8g).

\section{Conclusions}

(1) The strike-slip Fushun Basin hosts an Eocene (Lutetian) lacustrine oil shale interval (ca. 50-300 m) consisting of the lower lean oil shale unit (LOSU) and the upper rich oil shale unit (ROSU), which ranks among the main oil-shale deposits in 
the world (Dyni, 2003). As identified in outcrop areas, the ca. 8-10 $\mathrm{m}$ and 5-8 $\mathrm{m}$ thick depositional cycles record the stacking of massive and non-laminated oil shales in the LOSU and fine- and coarse-laminated oil shales in the ROSU, respectively.

(2) The concentrations of redox-sensitive trace elements (e.g. V/Ni, V/Cr and $\mathrm{Ni} / \mathrm{Co}$ ratios) in the oil shale deposits support that oxic to suboxic conditions were prevailing in the paleo-Jijuntun Lakes during deposition of the LOSU, and then evolved into approximately oxygen-deficient conditions during deposition of the ROSU. This is in accord with evidences from biomarkers (e.g. $\mathrm{Pr} / \mathrm{Ph}$ ratios).

(3) The organic matter $(\mathrm{OM})$ input is mainly from major terrestrial higher plant and minor aquatic organisms, characterized by a predominant type II kerogen in the LOSU. In contrast, the ROSU records the increasing OM input from lacustrine algae, which is consistent with a predominant type I kerogen. In addition, a bacterial contribution cannot be ruled out as revealed by representative biomarkers.

(4) The concentrations of salinity- and climate-sensitive trace elements (e.g. Sr/Ba, $\mathrm{Sr} / \mathrm{Cu}$ and $\mathrm{Rb} / \mathrm{Sr}$ ratios, and boron content) indicate that the freshwater paleo-Jijuntun Lakes, ca. 20-30 m deep, could possess unstable thermal stratification induced by warm/humid climate during deposition of the LOSU. However, the ca. $100 \mathrm{~m}$ deep water column might be significantly influenced by mildly brackish water during deposition of the ROSU, resulting in saline stratification superposed on pre-existing thermal stratification under warm to cool/humid to arid climate.

(5) The immature to low-mature oil shale deposits are characterized by varying concentrations of the studied trace elements. This result somewhat mirrors the 
differential accumulation of trace elements in worldwide coals and black shales

(Ketris and Yudovich, 2009). A systematical decrease (approximately one order of magnitude) in the concentrations of most trace elements (except for boron and Co) in the coaly oil shale in the lowermost LOSU, relative to those in the other oil shales in the Jijuntun Formation indicates the significant change of OM input from higher plant (especially coaly materials) to aquatic plankton. The normal enrichment of most trace elements (except for Mn and Mo) in the other oil shales in the Jijuntun Formation is representative of low to moderate productivities and aquatic OM influx. The elevated concentrations of boron and Co in the coaly oil shale and Mn in the other oil shales in the Jijuntun Formation may result from moderate insoluble sulfide precipitates, whereas the depleted Mo in the other oil shales in the Jijuntun Formation could be associated low to moderate productivities and/or incompletely oxygen-free conditions in the paleo-Jijuntun Lakes.

\section{Acknowledgements}

We gratefully acknowledge support from the China National Science Foundation (Grant 40972076), the Doctoral Actuation Fund from Hebei GEO University (Grant BQ201327) and the China Scholarship Council (Grant 2009101477). Several experts are also thanked for helpful discussions, including but not limited to Reinhard F. Sachsenhofer, Ronald C. Johnson, Susanne A.I. Strobl and Tim K. Lowenstein. The authors are grateful to Xiao-Feng Hu, Lei Yan and Chang-Sheng Miao for profile measurement and samples collection during fieldwork. We thank two anonymous reviewers and the editor Prof. Ralf Littke for their thoughtful reviews for the original manuscript.

\section{References}

Adegoke, A.K., Abdullah, W.H., Hakimi, M.H., Sarki Yandoka, B.M., 2014. Geochemical characterisation of Fika Formation in the Chad (Bornu) Basin, northeastern Nigeria: 
Implications for depositional environment and tectonic setting. Applied Geochemistry 43, $1-12$.

Akinlua, A., Adekola, S.A., Swakamisa, O., Fadipe, O.A., Akinyemi, S.A., 2010. Trace element characterisation of Cretaceous Orange Basin hydrocarbon source rocks. Applied Geochemistry 25, 1587-1595.

Amijaya, H., Schwarzbauer, J., Littke, R., 2006. Organic geochemistry of the Lower Suban coal seam, South Sumatra Basin, Indonesia: Palaeoecological and thermal metamorphism implications. Organic Geochemistry 37, 261-279.

Anadón, P., Cabrera, L., Julià, R., Roca, E., Rosell, L., 1989. Lacustrine oil-shale basins in tertiary grabens from NE Spain (Western European rift system). Palaeogeography, Palaeoclimatology, Palaeoecology 70, 7-28.

Audry, S., Blanc, G., Schäfer, J., Chaillou, G., Robert, S., 2006. Early diagenesis of trace metals (Cd, $\mathrm{Cu}, \mathrm{Co}, \mathrm{Ni}, \mathrm{U}, \mathrm{Mo}$, and $\mathrm{V}$ ) in the freshwater reaches of a macrotidal estuary. Geochimica et Cosmochimica Acta 70, 2264-2282.

Banerjee, I., Goodarzi, F., 1990. Paleoenvironment and sulfur-boron contents of the Mannville (Lower Cretaceous) coals of southern Alberta, Canada. Sedimentary Geology 67, 297-310.

Bechtel, A., Hámor-Vidó, M., Sachsenhofer, R.F., Reischenbacher, D., Gratzer, R., Püttmann, W., 2007. The middle Eocene Márkushegy subbituminous coal (Hungary): Paleoenvironmental implications from petrographical and geochemical studies. International Journal of Coal Geology 72, 33-52.

Bechtel, A., Sachsenhofer, R.F., Zdravkov, A., Kostova, I., Gratzer, R., 2005. Influence of floral assemblage, facies and diagenesis on petrography and organic geochemistry of the Eocene Bourgas coal and the Miocene Maritza-East lignite (Bulgaria). Organic Geochemistry 36, 1498-1522.

Beckmann, B., Flögel, S., Hofmann, P., Schulz, M., Wagner, T., 2005. Orbital forcing of Cretaceous river discharge in tropical Africa and ocean response. Nature 437, 241-244.

Berner, R.A., Raiswell, R., 1984. C/S method for distinguishing freshwater from marine sedimentary rocks. Geology 12, 365-368.

Bray, E.E., Evans, E.D., 1961. Distribution of $n$-paraffins as a clue to recognition of source beds. Geochimica et Cosmochimica Acta 22, 2-15.

Calvert, S.E., Pederson, T.F., 1993. Geochemistry of recent oxic and anoxic marine sediments: Implications for the geological record. Marine Geology 113, 67-88.

Cande, S.C., Kent, D.V., 1992. A new geomagnetic polarity time scale for the Late Cretaceous and Cenozoic. Journal of Geophysical Research 97, 13917-13951.

Cande, S.C., Kent, D.V., 1995. Revised calibration of the geomagnetic polarity timescale for the Late Cretaceous and Cenozoic. Journal of Geophysical Research 100, 6093-6095.

Carroll, A.R., Bohacs, K.M., 1999. Stratigraphic classification of ancient lakes: Balancing tectonic and climatic controls. Geology 27, 99-102.

Carroll, A.R., Bohacs, K.M., 2001. Lake-type controls on petroleum source rock potential in nonmarine basins. AAPG Bulletin 85, 1033-1053.

Chen, J.C., Hsu, C.N., Ho, K.S., 2003. Geochemistry of Cenozoic volcanic rocks and related ultramafic xenoliths from the Jilin and Heilongjiang provinces, northeast China. Journal of Asian Earth Sciences 21, 1069-1084.

Dai, S., Ren, D., Chou, C.L., Li, S., Jiang, Y., 2006. Mineralogy and geochemistry of the No. 6 Coal 
(Pennsylvanian) in the Junger Coalfield, Ordos Basin, China. International Journal of Coal Geology 66, 253-270.

Dai, S., Ren, D., Tang, Y., Yue, M., Hao, L., 2005. Concentration and distribution of elements in Late Permian coals from western Guizhou Province, China. International Journal of Coal Geology 61, 119-137.

Dai, S., Seredin, V.V., Ward, C.R., Hower, J.C., Xing, Y., Zhang, W., Song, W., Wang, P., 2015. Enrichment of U-Se-Mo-Re-V in coals preserved within marine carbonate successions: Geochemical and mineralogical data from the Late Permian Guiding Coalfield, Guizhou, China. Mineralium Deposita 50, 159-186.

Dawson, D., Grice, K., Alexander, R., Edwards, D., 2007. The effect of source and maturity on the stable isotopic compositions of individual hydrocarbons in sediments and crude oils from the Vulcan Sub-basin, Timor Sea, Northern Australia. Organic Geochemistry 38, 1015-1038.

Deng, H.W., Qian, K., 1993. Analysis on sedimentary geochemistry and environment. Science Technology Press, Gansu.

Duncan, A.D., Hamilton, R.F.M., 1988. Paleolimnology and organic geochemistry of the Middle Devonian in the Orcadian Basin. In: Fleets, A.J., Kelts, K., Talbot, M.R. (Eds.), Lacustrine petroleum source rocks. Geological Society Special Publication 40, pp. 173-201.

Durand, B., Nicaise, G., 1980. Procedures for kerogen isolations. In: Durand, B. (Ed.), Kerogen. Technip, Paris, pp. 35-53.

Dyni, J.R., 2003. Geology and resource of some world oil-shale deposits. Oil Shale 20, 193-252.

Ediger, V.Ş., Berk, I., Kösebalaban, A., 2014. Lignite resources of Turkey: Geology, reserves, and exploration history. International Journal of Coal Geology 131, 13-22.

Eugster, H.P., Surdam, R.C., 1973. Depositional environment of the Green River Formation of Wyoming: A preliminary report. GSA Bulletin 84, 1115-1120.

Foscolos, A.E., Powell, T.G., Gunther, P.R., 1976. The use of clay minerals and inorganic and organic geochemical indicators for evaluating the degree of diagenesis and oil generating potential of shales. Geochimica et Cosmochimica Acta 40, 953-966.

Fu, X., Wang, J., Zeng, Y., Cheng, J., Tano, F., 2011. Origin and mode of occurrence of trace elements in marine oil shale from the Shengli River Area, Northern Tibet, China. Oil Shale 28, 487-506.

Galarraga, F., Llamas, J.F., Martïnez, A., Martínez, M., Flamas, J.F., Márquez, G., 2008. V/Ni ratio as a parameter in palaeoenvironmental characterization of nonmature medium-crude oils from several Latin American basins. Journal of Petroleum Science and Engineering 61, 9-14.

George, S.C., Ruble, T.E., Dutkiewicz, A., Eadington, P.J., 2001. Assessing the maturity of oil trapped in fluid inclusions using molecular geochemistry data and visually-determined fluorescence colours. Applied Geochemistry 16, 451-473.

Goodarzi, F., Swaine, D.J., 1994. The influence of geological factors on the concentration of boron in Australian and Canadian coals. Chemical Geology 118, 301-318.

Goossens, H., de Leeuw, J.W., Schenck, P.A., Brassel, S.C., 1984. Tocopherols as likely precursors of pristane in ancient sediments and crude oils. Nature 312, 440-442.

Hall, P.B., Douglas, A.G., 1983. The distribution of cyclic alkanes in two lacustrine deposits. In: Bjorøy, M. (Eds.), Advances in organic geochemistry 1981. John Wiley, Chichester, England, pp. 576-587.

Hatch, J.R., Leventhal, J.S., 1992. Relationship between inferred redox potential of the depositional 
environment and geochemistry of the Upper Pennsylvanian (Missourian) Stark Shale Member of the Dennis Limestone, Wabaunsee Country, Kansas, U.S.A. Chemical Geology 99, 65-82.

He, Y.G., 2004. Mining and utilization of Chinese Fushun oil shale. Oil Shale 21, 259-264.

Hong, Y.C., Yang, Z.Q., Wang, S.T., Sun, X.J., Du, N.Q., Sun, M.R., Li, Y.G., 1980. A research on the strata and palaeontology of the Fushun Coal Field in Liaoning Province. Science Press, Beijing.

Huang, W.Y., Meinschein, W.G., 1979. Sterols as ecological indicators. Geochimica et Cosmochimica Acta 43, 739-745.

Huang, X.Z., Chen, C.Z., Jia, W.N., An, C.B., Zhou, A.F., Zhang, J.W., Jin, M., Xia, D.S., Chen, F.H., Grimm, E.C., 2015. Vegetation and climate history reconstructed from an alpine lake in central Tienshan Mountains since 8.5 ka BP. Palaeogeography, Palaeoclimatology, Palaeoecology 432, 36-48.

Huang, Z., Liu, Z., Dai, H., Xu, S., 1983. On the sedimentary environment of the coal-bearing formation in the Fushun coal basin. Acta Geologica Sinica 57, 261-269.

Huerta-Diaz, M.A., Morse, J.W., 1990. A quantitative method for determination of trace metal concentrations in sedimentary pyrite. Marine Chemistry 29, 119-144.

Hyacinthe, C., Van Cappellen, P., 2004. An authigenic iron phosphate phase in estuarine sediments: Composition, formation and chemical reactivity. Marine Chemistry 91, 227-251.

Johnson, E.A., 1990. Geology of the Fushun coalfield, Liaoning Province, People's Republic of China. International Journal of Coal Geology 14, 217-236.

Jones, B., Manning, D.A.C., 1994. Comparison of geochemical indices used for the interpretation of palaeoredox conditions in ancient mudstones. Chemical Geology 111, 111-129.

Katz, B.J., 1990. Controls on distribution of lacustrine source rocks through time and space. In: Katz, B.J. (Eds.), Lacustrine basin exploration - case studies and modern analogs. AAPG Memoir 50, pp. 61-76.

Ketris, M.P., Yudovich, Y.E., 2009. Estimations of Clarkes for Carbonaceous biolithes: World averages for trace element contents in black shales and coals. International Journal of Coal Geology 78, 135-148.

Koopmans, M.P., De Leeuw, J.W., Sinninghe Damsté, J.S., 1997. Novel cyclised and aromatised diagenetic products of $\beta$-carotene in the Green River Shale. Organic Geochemistry 26, $451-466$.

Kraatz, B.P., Geisler, J.H., 2010. Eocene-Oligocene transition in Central Asia and its effects on mammalian evolution. Geology 38, 111-114.

Langford, F.F., Blanc-Valleron, M.M., 1990. Interpreting Rock-Eval pyrolysis data using graphs of pyrolyzable hydrocarbons vs. total organic carbon. AAPG Bulletin 74, 799-804.

López, L., Lo Mónaco, S., Galarraga, F., Lira, A., Cruz, C., 1995. V/Ni ratio in maltene and asphaltene fractions of crude oils from the west Venezuelan basin: Correlation studies. Chemical Geology 119, 255-262.

López, L., Lo Mónaco, S., 2004. Geochemical implications of trace elements and sulfur in the saturate, aromatic and resin fractions of crude oil from the Mara and Mara Oeste fields, Venezuela. Fuel 83, 365-374.

Lewan, M.D., Maynard, J.B., 1982. Factors controlling enrichment of vanadium and nickel in the bitumen of organic sedimentary rocks. Geochimica et Cosmochimica Acta 46, 2547-2560.

Lewan, M.D., 1984. Factors controlling the proportionality of vanadium to nickel in crude oils. 
Geochimica et Cosmochimica Acta 48, 2231-2238.

Liu, R., Liu, Z., Sun, P., Xu, Y., Liu, D., Yang, X., Zhang, C., 2015. Geochemistry of the Eocene Jijuntun Formation oil shale in the Fushun Basin, northeast China: Implications for source-area weathering, provenance and tectonic setting. Chemie der Erde-Geochemistry 75, $105-116$.

Liu, Z., Yang, H., Dong, Q., Zhu, J., Guo, W., 2009. Oil shale in China. Petroleum Industry Press, Beijing.

Lu, H., Yu, H., Ding, Y., Zhang, Q., 1983. Changing stress field in the middle segment of the Tan-Lu fault zone, eastern China. Tectonophysics 98, 253-270.

Mello, M.R., Telnaes, N., Gaglianone, P.C., Chicarelli, M.I., Brassell, S.C., Maxwell, J.R., 1988. Organic geochemical characterisation of depositional palaeoenvironments of source rocks and oils in Brazilian marginal basins. Organic Geochemistry 13, 31-45.

Meng, Q., Liu, Z., Bruch, A.A., Liu, R., Hu, F., 2012. Palaeoclimatic evolution during Eocene and its influence on oil shale mineralisation, Fushun basin, China. Journal of Asian Earth Sciences 45, 95-105.

Meyers, P.A., 1997. Organic geochemical proxies of paleoceanographic, paleolimnologic, and paleoclimatic processes. Organic Geochemistry 27, 213-250.

Mohialdeen, I.M.J., Raza, S.M., 2013. Inorganic geochemical evidence for the depositional facies associations of the Upper Jurassic Chia Gara Formation in NE Iraq. Arabian Journal of Geosciences 6, 4755-4770.

Moldowan, J.M., Sundararaman, P., Schoell, M., 1986. Sensitivity of biomarker properties to depositional environment and/or source input in the Lower Toarcian of SW-Germany. Organic Geochemistry 10, 915-926.

Mongenot, T., Tribovillard, N., Desprairies, A., Lallier-Vergès, E., Laggoun-Defarge, F., 1996. Trace elements as palaeoenvironmental markers in strongly mature hydrocarbon source rocks: The Cretaceous La Luna Formation of Venezuela. Sedimentary Geology 103, 23-37.

Morel, F.M.M., Price, N.M., 2003. The biogeochemical cycles of trace metals in the ocean. Science 300, 944-947.

Murphy, S.M., McCormick, A., Eglinton, G., 1967. Perhydro- $\beta$-Carotene in the Green River Shale. Science 157, 1040-1042.

Olsen, P.E., 1990. Tectonic, climatic, and biotic modulation of lacustrine ecosystems-examples from Newark Supergroup of eastern North America. In: Katz, B.J. (Eds.), Lacustrine basin exploration — case studies and modern analogs. AAPG Memoir 50, pp. 209-224.

Peters, K.E., 1986. Guidelines for evaluating petroleum source rock using programmed pyrolysis. AAPG Bulletin 70, 318-329.

Peters, K.E., Moldowan, J.M., 1993. The biomarker guide: Interpreting molecular fossils in petroleum and ancient sediments. Prentice Hall, Englewood Cliffs, New Jersey.

Powell, T.G., 1988. Pristane/phytane ratio as environmental indicator. Nature 333, 604.

Quinby-Hunt, M.S., Wilde, P., 1994. Thermodynamic zonation in the black shale facies based on iron-manganese-vanadium content. Chemical Geology 113, 297-317.

Repeta, D.J., 1993. A high resolution historical record of Holocene anoxygenic primary production in the Black Sea. Geochimica et Cosmochimica Acta 57, 4337-4342.

Ren, J., Tamaki, K., Li, S., Zhang, J., 2002. Late Mesozoic and Cenozoic rifting and its dynamic setting in Eastern China and adjacent areas. Tectonophysics 344, 175-205. 
Roehler, H.W., 1992. Correlation, composition, areal distribution, and thickness of Eocene stratigraphic units, greater Green River basin, Wyoming, Utah, and Colorado. U.S. Geological Survey Professional Paper 1506-E.

Roy, D.K., Roser, B.P., 2013. Climatic control on the composition of Carboniferous-Permian Gondwana sediments, Khalaspir basin, Bangladesh. Gondwana Research 23, 1163-1171.

Sarki Yandoka, B.M., Abdullah, W.H., Abubakar, M.B., Hakimi, M.H., Adegoke, A.K., 2015. Geochemical characterisation of Early Cretaceous lacustrine sediments of Bima Formation, Yola Sub-basin, Northern Benue Trough, NE Nigeria: Organic matter input, preservation, paleoenvironment and palaeoclimatic conditions. Marine and Petroleum Geology 61, 82-94.

Scalan, E.S., Smith, J.E., 1970. An improved measure of the odd-even predominance in the normal alkanes of sediment extracts and petroleum. Geochimica et Cosmochimica Acta 34, 611-620.

Seifert, W.K., Moldowan, J.M., 1986. Use of biological markers in petroleum exploration. In: Johns, R.B. (Ed.), Biological markers in the sedimentary record. Elsevier, Amsterdam, pp. 261-290.

Shi, C., Cao, J., Bao, J., Zhu, C., Jiang, X., Wu, M., 2015. Source characterization of highly mature pyrobitumens using trace and rare earth element geochemistry: Sinian-Paleozoic paleo-oil reservoirs in South China. Organic Geochemistry 83-84, 77-93.

Sinninghe Damsté, J.S., Kenig, F., Koopmans, M.P., Köster, J., Schouten, S., Hayes, J.M., de Leeuw, J.W., 1995. Evidence for gammacerane as an indicator of water column stratification. Geochimica et Cosmochimica Acta 59, 1895-1900.

Smith, M.E., Carroll, A.R., Singer, B.S., 2008. Synoptic reconstruction of a major ancient lake system: Eocene Green River Formation, western United States. GSA Bulletin 120, 54-84.

Sobel, E.R., Strecker, M.R., 2003. Uplift, exhumation and precipitation: Tectonic and climatic control of Late Cenozoic landscape evolution in the northern Sierras Pampeanas, Argentina. Basin Research 15, 431-451.

Steinke, S., Groeneveld, J., Johnstone, H., Rendle-Bühring, R., 2010. East Asian summer monsoon weakening after $7.5 \mathrm{Ma}$ : Evidence from combined planktonic foraminifera $\mathrm{Mg} / \mathrm{Ca}$ and $\delta^{18} \mathrm{O}$ (ODP Site 1146; northern South China Sea). Palaeogeography, Palaeoclimatology, Palaeoecology 289, 33-43.

Strecker, M.R., Alonso, R.N., Bookhagen, B., Carrapa, B., Hilley, G.E., Sobel, E.R., Trauth, M.H., 2007. Tectonics and climate of the southern central Andes. Annual Review of Earth \& Planetary Sciences 35, 747-787.

Strobl, S.A.I., Sachsenhofer, R.F., Bechtel, A., Gratzer, R., Gross, D., Bokhari, S.N.H., Liu, R., Liu, Z., Meng, Q., Sun, P., 2014a. Depositional environment of oil shale within the Eocene Jijuntun Formation in the Fushun Basin (NE China). Marine and Petroleum Geology 56, 166-183.

Strobl, S.A.I., Sachsenhofer, R.F., Bechtel, A., Meng, Q., 2014b. Paleoenvironment of the Eocene coal seam in the Fushun Basin (NE China): Implications from petrography and organic geochemistry. International Journal of Coal Geology 134-135, 24-37.

Tegelaar, E.W., Matthezing, R.M., Jansen, J.B.H., Horsfield, B., de Leeuw, J.W., 1989. Possible origin of $n$-alkanes in high-wax crude oils. Nature 342, 529-531.

ten Haven, H.L., de Leeuw, J.W., Rullkötter, J., Sinninghe Damsté, J.S., 1987. Restricted utility of the pristane/phytane ratio as a palaeoenvironmental indicator. Nature 330, 641-643.

Tissot, B., Welte, D.H., 1984. Petroleum Formation and Occurrence (2nd ed.) Springer-Verlag, Heidelberg.

Tribovillard, N., Algeo, T.J., Lyons, T., Riboulleau, A., 2006. Trace metals as paleoredox and 
paleoproductivity proxies: An update. Chemical Geology 232, 12-32.

Utescher, T., Mosbrugger, V., 2007. Eocene vegetation patterns reconstructed from plant diversity-A global perspective. Palaeogeography, Palaeoclimatology, Palaeoecology 247, 243-271.

Volkman, J.K., 2003. Sterols in microorganisms. Applied Microbiology and Biotechnology 60, 495-506.

Walker, D., 2011. The frequency of lamination in the sediments of Lake Barrine, tropical north-east Australia, during the last five millennia. Palaeogeography, Palaeoclimatology, Palaeoecology 299, 214-226.

Wang, H., Yang, X., Zhu, B., Fan, S., Dai, T., 1989. K-Ar geochronology and evolution of Cenozoic volcanic rocks in eastern China. Chinese Journal of Geochemistry 8, 1-14.

Wang, Q., Ferguson, D.K., Feng, G.P., Ablaev, A.G., Wang, Y.F., Yang, J., Li, Y.L., Li, C.S., 2010. Climatic change during the Palaeocene to Eocene based on fossil plants from Fushun, China. Palaeogeography, Palaeoclimatology, Palaeoecology 295, 323-331.

Waseda, A., Nishita, H., 1998. Geochemical characteristics of terrigenous- and marine-sourced oils in Hokkaido, Japan. Organic Geochemistry 28, 27-41.

Wu, C., Wang, X., Liu, G., Li, S., Mao, X., Li, X., 2002. Study on dynamics of tectonic evolution in the Fushun Basin, Northeast China. Science in China Series D: Earth Sciences 45, 311-324.

Wu, C., Yang, Q., Zhu, Z., Liu, G., Li, X., 2000. Thermodynamic analysis and simulation of coal metamorphism in the Fushun Basin, China. International Journal of Coal Geology 44, 149-168.

Wu, F.Y., Sun, D.Y., Ge, W.C., Zhang, Y.B., Grant, M.L., Wilde, S.A., Jahn, B.M., 2011. Geochronology of the Phanerozoic granitoids in northeastern China. Journal of Asian Earth Sciences 41, 1-30.

Xu, J., Zhu, G., 1994. Tectonic models of the Tan-Lu fault zone, eastern China. International Geology Review 36, 771-784.

Xu, S.C., Liu, Z.J., Dong, Q.S., Liu, S.Y., Liu, R., Meng, Q.T., 2012. Eocene sedimentary evolution and its control over coal \& oil shale development in the Fushun Coalfield. Journal of China University of Petroleum 36, 45-52.

Xu, S.C., Liu, Z.J., Dong, Q.S., Liu, R., Meng, Q.T., Hu, X.F., 2013. Characteristics and origin of organic geochemistry from the Eocene source rocks, Fushun Basin, Liaoning Province. Journal of China University of Mining \& Technology 42, 790-800.

Zachos, J., Pagani, M., Sloan, L., Thomas, E., Billups, K., 2001. Trends, rhythms, and aberrations in global climate 65 Ma to present. Science 292, 685-693.

Zakir Hossain, H.M., Sampei, Y., Roser, B.P., 2009. Characterization of organic matter and depositional environment of Tertiary mudstones from the Sylhet Basin, Bangladesh. Organic Geochemistry 40, 743-754.

Zhao, C., Wei, D., Liu, H., An, J., Wang, J., 1992. A magnetostratigraphic study of Lower Tertiary in the northeast oil-gas-bearing region in China. Acta Petrolei Sinica 13, 226-231. 


\section{Table 1}

Trace element compositions and relevant ratios for the Eocene lacustrine oil shale samples studied.

\begin{tabular}{|c|c|c|c|c|c|c|c|c|c|c|c|c|c|c|c|c|c|c|c|c|c|c|c|c|}
\hline \multirow{2}{*}{$\begin{array}{l}\text { Sample } \\
\text { ID }\end{array}$} & \multirow{2}{*}{$\begin{array}{l}\text { Position } \\
\text { (m) }\end{array}$} & \multirow[b]{2}{*}{ Lithology } & \multicolumn{13}{|c|}{ Trace element compositions (ppm) } & \multicolumn{9}{|c|}{ Trace element ratios } \\
\hline & & & $\begin{array}{l}\text { Bor } \\
\text { on }\end{array}$ & $\mathrm{v}$ & $\mathrm{Ni}$ & $\mathrm{Sr}$ & $\mathrm{Ba}$ & $\mathrm{Cr}$ & Co & $\mathrm{Cu}$ & $\mathrm{Zn}$ & $\mathrm{Mn}$ & Mo & $\mathrm{Ga}$ & $\mathrm{Rb}$ & $\begin{array}{l}\mathrm{V} / \\
\mathrm{Ni}\end{array}$ & $\begin{array}{l}\mathrm{V} /(\mathrm{V} \\
+\mathrm{Ni})\end{array}$ & $\mathrm{V} / \mathrm{Cr}$ & $\mathrm{Ni} / \mathrm{Co}$ & $\begin{array}{l}(\mathrm{Cu}+\mathrm{M} \\
\text { o) } / \mathrm{Zn}\end{array}$ & $\mathrm{Sr} / \mathrm{Ba}$ & $\mathrm{Sr} / \mathrm{Cu}$ & $\mathrm{Ga} / \mathrm{Rb}$ & $\mathrm{Rb} / \mathrm{Sr}$ \\
\hline $\mathrm{X} 78-1$ & 159.3 & os., fn. lam., gray to dark gray & 47 & 68.8 & 32.8 & 652 & 403 & 74 & 10.8 & 28 & 52 & 1,889 & 0.32 & 14 & 49 & 2.1 & 0.7 & 0.9 & 3.0 & 0.5 & 1.6 & 23.2 & 0.3 & 0.1 \\
\hline $\mathrm{X} 74-1$ & 151.8 & os., fn. lam., gray, pyrite & 76 & 92.3 & 60.2 & 686 & 487 & 99 & 23.2 & 36 & 92 & 1,031 & 0.56 & 19 & 43 & 1.5 & 0.6 & 0.9 & 2.6 & 0.4 & 1.4 & 19.0 & 0.4 & 0.1 \\
\hline X67-1 & 140.2 & os., crs. lam., dark gray, siderite & 95 & 123.8 & 91.0 & 344 & 463 & 123 & 20.2 & 46 & 89 & 644 & 0.96 & 22 & 77 & 1.4 & 0.6 & 1.0 & 4.5 & 0.5 & 0.7 & 7.4 & 0.3 & 0.2 \\
\hline X64-1 & 136.4 & os., crs. lam., dark gray & 33 & 115.3 & 62.1 & 124 & 495 & 110 & 22.0 & 41 & 94 & 873 & 1.37 & 21 & 67 & 1.9 & 0.6 & 1.1 & 2.8 & 0.4 & 0.3 & 3.0 & 0.3 & 0.5 \\
\hline X63-1 & 133.6 & os., crs. lam., gray to dark gray & 20 & 115.1 & 59.1 & 101 & 369 & 158 & 19.9 & 38 & 73 & 406 & 1.22 & 18 & 52 & 1.9 & 0.7 & 0.7 & 3.0 & 0.5 & 0.3 & 2.7 & 0.3 & 0.5 \\
\hline X61-1 & 128.1 & os., fn. lam., dark gray, fish & 38 & 98.5 & 37.1 & 108 & 406 & 99 & 13.9 & 31 & 63 & 1,171 & 0.56 & 15 & 51 & 2.7 & 0.7 & 1.0 & 2.7 & 0.5 & 0.3 & 3.5 & 0.3 & 0.5 \\
\hline X59-1 & 124.9 & os., fn. lam., gray to dark gray & 42 & 113.3 & 56.9 & 142 & 405 & 100 & 18.6 & 38 & 77 & 1,106 & 0.97 & 19 & 52 & 2.0 & 0.7 & 1.1 & 3.1 & 0.5 & 0.4 & 3.7 & 0.4 & 0.4 \\
\hline X52-1 & 110.4 & os., fn. lam., gray, pyrite & 24 & 105.1 & 48.1 & 140 & 430 & 80 & 16.1 & 29 & 69 & 1,969 & 1.04 & 15 & 41 & 2.2 & 0.7 & 1.3 & 3.0 & 0.4 & 0.3 & 4.8 & 0.4 & 0.3 \\
\hline X51-1 & 106.0 & os., fn. lam., dark gray & 16 & 94.9 & 41.6 & 103 & 309 & 70 & 15.3 & 25 & 50 & 2,155 & 1.05 & 12 & 43 & 2.3 & 0.7 & 1.4 & 2.7 & 0.5 & 0.3 & 4.1 & 0.3 & 0.4 \\
\hline $\mathrm{X} 45-1$ & 96.4 & os., crs. lam., dark gray, fish & 21 & 129.6 & 70.3 & 113 & 458 & 130 & 23.7 & 47 & 90 & 844 & 1.37 & 21 & 56 & 1.8 & 0.6 & 1.0 & 3.0 & 0.5 & 0.2 & 2.4 & 0.4 & 0.5 \\
\hline X38-1 & 86.9 & os., crs. lam., dark gray & 23 & 118.5 & 60.8 & 130 & 511 & 119 & 22.0 & 41 & 91 & 750 & 1.16 & 21 & 63 & 2.0 & 0.7 & 1.0 & 2.8 & 0.5 & 0.3 & 3.2 & 0.3 & 0.5 \\
\hline X36-1 & 80.7 & os., crs. lam., dark gray, siderite & 22 & 130.0 & 57.7 & 125 & 530 & 120 & 20.5 & 38 & 86 & 1,163 & 1.21 & 21 & 63 & 2.3 & 0.7 & 1.1 & 2.8 & 0.5 & 0.2 & 3.3 & 0.3 & 0.5 \\
\hline Average & & & 38 & 110.6 & 58.0 & 221 & 435 & 108 & 19.2 & 37 & 78 & 1,111 & 1.02 & 19 & 56 & 2.0 & 0.7 & 1.0 & 3.0 & 0.5 & 0.5 & 6.3 & 0.3 & 0.4 \\
\hline \multicolumn{25}{|c|}{ Jijuntun Formation — Lean oil shale unit (LOSU) } \\
\hline $\mathrm{X} 35-2$ & 74.0 & os., mas., gray, silty lenses & 25 & 139.5 & 72.1 & 296 & 1,151 & 136 & 32.6 & 49 & 99 & 1,399 & 1.03 & 27 & 58 & 1.9 & 0.7 & 1.0 & 2.2 & 0.5 & 0.3 & 6.1 & 0.5 & 0.2 \\
\hline $\mathrm{X} 31-1$ & 66.7 & os., nonlam., dark gray, siderite & 20 & 129.0 & 42.7 & 70 & 371 & 94 & 20.4 & 29 & 70 & 2,751 & 0.95 & 16 & 32 & 3.0 & 0.8 & 1.4 & 2.1 & 0.4 & 0.2 & 2.4 & 0.5 & 0.5 \\
\hline $\mathrm{X} 30-1$ & 63.5 & os., mas., grayish, silty lenses & 18 & 125.8 & 42.8 & 77 & 368 & 91 & 20.7 & 27 & 69 & 2,419 & 0.77 & 16 & 33 & 2.9 & 0.7 & 1.4 & 2.1 & 0.4 & 0.2 & 2.8 & 0.5 & 0.4 \\
\hline
\end{tabular}




\begin{tabular}{|c|c|c|c|c|c|c|c|c|c|c|c|c|c|c|c|c|c|c|c|c|c|c|c|c|}
\hline $\mathrm{X} 26-1$ & 57.4 & os., mas., grayish, silty lenses & 26 & 109.5 & 52.2 & 123 & 444 & 95 & 19.0 & 38 & 70 & 922 & 1.12 & 17 & 56 & 2.1 & 0.7 & 1.1 & 2.8 & 0.6 & 0.3 & 3.2 & 0.3 & 0.5 \\
\hline X23-1 & 51.0 & os., nonlam., gray, leaf, gastropod & 13 & 174.6 & 48.6 & 87 & 494 & 114 & 21.6 & 31 & 66 & 3,249 & 0.84 & 16 & 43 & 3.6 & 0.8 & 1.5 & 2.3 & 0.5 & 0.2 & 2.8 & 0.4 & 0.5 \\
\hline X22-1 & 47.5 & os., nonlam., gray, leaf & 17 & 95.0 & 44.6 & 40 & 301 & 80 & 31.6 & 25 & 82 & 3,586 & 0.87 & 11 & 33 & 2.1 & 0.7 & 1.2 & 1.4 & 0.3 & 0.1 & 1.6 & 0.3 & 0.8 \\
\hline X19-1 & 41.9 & os., nonlam., gray, leaf, siderite & 23 & 80.5 & 49.7 & 45 & 294 & 84 & 34.1 & 23 & 94 & 3,603 & 0.97 & 13 & 36 & 1.6 & 0.6 & 1.0 & 1.5 & 0.3 & 0.2 & 1.9 & 0.4 & 0.8 \\
\hline X13-1 & 32.2 & os., nonlam., gray, leaf & 29 & 104.9 & 47.7 & 38 & 230 & 79 & 17.5 & 26 & 67 & 1,961 & 1.01 & 13 & 43 & 2.2 & 0.7 & 1.3 & 2.7 & 0.4 & 0.2 & 1.5 & 0.3 & 1.1 \\
\hline X11-2 & 29.6 & cos., mas., med. gray, coal lyr. & 45 & 5.6 & 7.0 & 8 & 13 & 6 & 10.9 & 2 & 16 & 55 & 0.19 & 1 & 3 & 0.8 & 0.4 & 0.9 & 0.6 & 0.1 & 0.6 & 3.5 & 0.2 & 0.4 \\
\hline Average & & & 24 & 107.2 & 45.3 & 87 & 407 & 87 & 23.1 & 28 & 70 & 2,216 & 0.86 & 14 & 38 & 2.3 & 0.7 & 1.2 & 2.0 & 0.4 & 0.2 & 2.9 & 0.4 & 0.6 \\
\hline
\end{tabular}

Position = meters from profile base; os. = oil shale; cos. = coaly oil shale; coal lyr. = interbedded coal layer $(<2 \mathrm{~cm})$; mas. = massive; nonlam. = non-lamination; crs. lam. =

coarse lamination $(\geq 2 \mathrm{~mm})$; fn. lam. = fine lamination $(<2 \mathrm{~mm})$; leaf $=$ leaf remains or fragments; fish $=$ fish remains or scales; Shales ${ }^{\dagger}=$ averages of trace element

concentrations in world black shales (data from Ketris and Yudovich, 2009). 


\section{Table 2}

Isolated kerogen elements, Rock-Eval pyrolysis results and extractable organic matter for the Eocene lacustrine oil shale samples studied.

\begin{tabular}{|c|c|c|c|c|c|c|c|c|c|c|c|c|c|c|c|c|c|c|c|c|c|c|c|c|}
\hline \multirow[b]{2}{*}{$\begin{array}{l}\text { Sample } \\
\text { ID }\end{array}$} & \multirow[b]{2}{*}{$\begin{array}{l}\text { Position } \\
\text { (m) }\end{array}$} & \multicolumn{9}{|c|}{ Isolated kerogen elements } & \multicolumn{9}{|c|}{ Rock-Eval pyrolysis parameters } & \multicolumn{5}{|c|}{ Extractable organic matter } \\
\hline & & $\begin{array}{l}\mathrm{C} \\
(\%)\end{array}$ & $\begin{array}{l}\mathrm{H} \\
(\%)\end{array}$ & $\begin{array}{l}\mathrm{O} \\
(\%)\end{array}$ & $\begin{array}{l}\mathrm{N} \\
(\%)\end{array}$ & $\begin{array}{l}\mathrm{S} \\
(\%)\end{array}$ & $\mathrm{N}$ & $\mathrm{C} /$ & $\begin{array}{l}\text { Atomic } \\
\mathrm{H} / \mathrm{C}\end{array}$ & $\begin{array}{l}\text { Atomic } \\
\mathrm{O} / \mathrm{C}\end{array}$ & $\begin{array}{l}\text { тОС } \\
\text { (wt.\%) }\end{array}$ & $\begin{array}{l}T_{\max } \\
\left({ }^{\circ} \mathrm{C}\right)\end{array}$ & $\begin{array}{l}\mathrm{S}_{1} \\
(\mathrm{mgHC} \\
/ \mathrm{g})\end{array}$ & $\begin{array}{l}\mathrm{S}_{2} \\
(\mathrm{mgHC} \\
/ \mathrm{g})\end{array}$ & $\begin{array}{l}\mathrm{S}_{3} \\
(\mathrm{mgC} \\
\left.\mathrm{O}_{2} / \mathrm{g}\right)\end{array}$ & $\begin{array}{l}\mathrm{S}_{1}+\mathrm{S}_{2} \\
(\mathrm{mgHC} / \mathrm{g} \\
)\end{array}$ & PI & $\begin{array}{l}\mathrm{HI} \\
(\mathrm{mgHC} \\
/ \mathrm{gTOC})\end{array}$ & $\begin{array}{l}\text { OI } \\
\left(\mathrm{mgCO}_{2} /\right. \\
\text { gTOC) }\end{array}$ & $\begin{array}{l}\text { EOM } \\
(\mathrm{mg} / \mathrm{g} \\
\text { TOC) }\end{array}$ & $\begin{array}{l}\text { Sat. } \\
\mathrm{HC} \\
(\%)\end{array}$ & $\begin{array}{l}\text { Aro. } \\
\mathrm{HC} \\
(\%)\end{array}$ & $\begin{array}{l}\text { NSO } \\
(\%)\end{array}$ & $\begin{array}{l}\text { Asp. } \\
(\%)\end{array}$ \\
\hline \multicolumn{25}{|c|}{ Jijuntun Formation - ROSU } \\
\hline $\mathrm{X} 78-1$ & 159.3 & 62.5 & 8.2 & 4.2 & 2.0 & 13.5 & 32 & 5 & 1.57 & 0.05 & 12.26 & 446 & 1.7 & 71.9 & 2.1 & 73.6 & 0.02 & 586 & 17 & 36 & 48 & 13 & 33 & 6 \\
\hline $\mathrm{X} 74-1$ & 151.8 & 61.2 & 7.7 & 4.9 & 2.7 & 12.6 & 23 & 5 & 1.52 & 0.06 & 16.91 & 444 & 2.0 & 90.0 & 3.8 & 91.9 & 0.02 & 532 & 23 & 58 & 41 & 18 & 35 & 7 \\
\hline $\mathrm{X} 67-1$ & 140.2 & 67.2 & 8.6 & 6.8 & 1.8 & 7.5 & 37 & 9 & 1.54 & 0.08 & 5.36 & 444 & 0.9 & 25.2 & 0.8 & 26.0 & 0.03 & 470 & 14 & 20 & 39 & 9 & 45 & 7 \\
\hline X64-1 & 136.4 & 49.1 & 5.9 & 6.1 & 2.4 & 5.0 & 21 & 10 & 1.45 & 0.09 & 5.96 & 445 & 0.7 & 30.9 & 1.1 & 31.6 & 0.02 & 518 & 18 & 20 & 36 & 6 & 52 & 6 \\
\hline X63-1 & 133.6 & 63.4 & 7.6 & 5.2 & 2.8 & 10.7 & 23 & 6 & 1.44 & 0.06 & 18.08 & 445 & 2.3 & 109.5 & 2.6 & 111.8 & 0.02 & 606 & 14 & & & & & \\
\hline X61-1 & 128.1 & 57.5 & 7.3 & 4.4 & 1.7 & 12.1 & 33 & 5 & 1.53 & 0.06 & 18.81 & 444 & 1.5 & 123.5 & 2.9 & 125.0 & 0.01 & 656 & 15 & 84 & 40 & 13 & 41 & 5 \\
\hline X59-1 & 124.9 & 65.0 & 9.0 & 4.8 & 2.2 & 9.4 & 34 & 7 & 1.66 & 0.06 & 17.03 & 442 & 2.4 & 90.5 & 6.5 & 92.9 & 0.03 & 531 & 38 & & & & & \\
\hline X52-1 & 110.4 & 63.4 & 9.2 & 6.3 & 2.0 & 7.0 & 31 & 9 & 1.75 & 0.07 & 16.52 & 443 & 2.7 & 97.3 & 0.8 & 100.0 & 0.03 & 589 & 5 & 76 & 35 & 18 & 42 & 6 \\
\hline X51-1 & 106.0 & 52.7 & 6.3 & 6.2 & 2.5 & 9.4 & 21 & 6 & 1.44 & 0.09 & 14.30 & 441 & 1.6 & 76.1 & 1.0 & 77.7 & 0.02 & 532 & 7 & & & & & \\
\hline X45-1 & 96.4 & 64.7 & 8.6 & 5.0 & 2.7 & 11.7 & 28 & 6 & 1.60 & 0.06 & 8.14 & 442 & 1.6 & 43.8 & 3.4 & 45.4 & 0.04 & 538 & 41 & 27 & 28 & 10 & 57 & 5 \\
\hline X42-1 & 90.5 & 65.2 & 8.6 & 7.2 & 1.8 & 14.4 & 35 & 5 & 1.59 & 0.08 & 16.28 & 440 & 1.5 & 105.2 & 2.1 & 106.7 & 0.01 & 646 & 13 & 73 & 34 & 21 & 41 & 4 \\
\hline X38-1 & 86.9 & 60.2 & 8.1 & 4.7 & 1.9 & 5.6 & 32 & 11 & 1.62 & 0.06 & 9.58 & 441 & 1.1 & 54.3 & 2.4 & 55.5 & 0.02 & 567 & 25 & & & & & \\
\hline X36-1 & 80.7 & 58.8 & 6.2 & 4.8 & 2.4 & 6.4 & 25 & 9 & 1.27 & 0.06 & 5.68 & 440 & 0.3 & 31.6 & 1.2 & 31.9 & 0.01 & 557 & 21 & 16 & 27 & 27 & 42 & 3 \\
\hline Average & & 60.8 & 7.8 & 5.4 & 2.2 & 9.6 & 29 & 7 & 1.54 & 0.07 & 12.69 & 443 & 1.6 & 73.1 & 2.4 & 74.6 & 0.02 & 564 & 19 & 46 & 36 & 15 & 43 & 5 \\
\hline \multicolumn{25}{|c|}{ Jijuntun Formation — LOSU } \\
\hline $\mathrm{X} 35-2$ & 74.0 & 59.5 & 5.5 & 7.5 & 2.9 & 4.2 & 21 & 14 & 1.12 & 0.09 & 2.77 & 438 & 0.2 & 10.7 & 2.3 & 10.9 & 0.02 & 386 & 84 & 5 & 23 & 21 & 47 & 9 \\
\hline X31-1 & 66.7 & 61.5 & 6.0 & 5.9 & 1.8 & 3.0 & 35 & 20 & 1.18 & 0.07 & 5.47 & 437 & 0.2 & 20.4 & 2.6 & 20.5 & 0.01 & 372 & 47 & 7 & 28 & 27 & 34 & 10 \\
\hline
\end{tabular}




\begin{tabular}{|c|c|c|c|c|c|c|c|c|c|c|c|c|c|c|c|c|c|c|c|c|c|c|c|c|}
\hline X30-1 & 63.5 & 55.9 & 6.3 & 5.8 & 2.5 & 2.0 & 22 & 29 & 1.35 & 0.08 & 2.62 & 435 & 0.1 & 9.8 & 2.1 & 9.9 & 0.01 & 373 & 78 & 4 & 19 & 34 & 44 & 3 \\
\hline X26-1 & 57.4 & 61.0 & 6.3 & 8.0 & 2.4 & 2.0 & 25 & 30 & 1.24 & 0.10 & 2.25 & 432 & 0.2 & 10.1 & 1.8 & 10.3 & 0.02 & 449 & 81 & & & & & \\
\hline X23-1 & 51.0 & 56.8 & 5.9 & 10.4 & 2.7 & 4.2 & 21 & 13 & 1.25 & 0.14 & 4.20 & 430 & 0.1 & 8.9 & 2.4 & 9.0 & 0.01 & 212 & 58 & & & & & \\
\hline $\mathrm{X} 22-1$ & 47.5 & 61.3 & 6.1 & 9.5 & 2.2 & 5.1 & 28 & 12 & 1.18 & 0.12 & 5.44 & 431 & 0.8 & 20.4 & 1.7 & 21.1 & 0.04 & 374 & 31 & 20 & 10 & 45 & 42 & 3 \\
\hline X19-1 & 41.9 & 66.3 & 5.7 & 10.6 & 2.1 & 4.7 & 31 & 14 & 1.03 & 0.12 & 5.14 & 430 & 0.8 & 19.7 & 4.2 & 20.5 & 0.04 & 383 & 81 & & & & & \\
\hline X13-1 & 32.2 & 53.9 & 4.1 & 7.4 & 1.4 & 4.3 & 39 & 12 & 0.90 & 0.10 & 6.16 & 429 & 1.0 & 20.3 & 1.1 & 21.2 & 0.05 & 329 & 17 & 29 & 16 & 30 & 50 & 4 \\
\hline X11-2 & 29.6 & 69.2 & 6.5 & 10.0 & 2.0 & 6.1 & 35 & 11 & 1.13 & 0.11 & 30.27 & 429 & 2.6 & 118.1 & 17.9 & 120.7 & 0.02 & 390 & 59 & 36 & 3 & 17 & 64 & 16 \\
\hline Average & & 60.6 & 5.8 & 8.3 & 2.2 & 4.0 & 29 & 17 & 1.15 & 0.10 & 7.15 & 432 & 0.7 & 26.5 & 4.0 & 27.1 & 0.02 & 363 & 60 & 17 & 16 & 29 & 47 & 8 \\
\hline
\end{tabular}

Position = meters from profile base $;$ TOC $=$ total organic carbon; $T_{\max }=$ temperature with maximum hydrocarbon generation; $\mathrm{S}_{1}=$ free hydrocarbons; $\mathrm{S}_{2}=$ pyrolytic

hydrocarbon yield; $\mathrm{S}_{3}=$ pyrolytic $\mathrm{CO}_{2}$ yield $;\left(\mathrm{S}_{1}+\mathrm{S}_{2}\right)=$ generative index; $\mathrm{PI}=$ production index; $\mathrm{HI}=$ hydrogen index; OI = oxygen index; EOM = extractable organic

matter; Sat. $\mathrm{HC}=$ saturated hydrocarbons; Aro. $\mathrm{HC}=$ aromatic hydrocarbons; Asp. $=$ asphaltenes. 
Table 3

Identified peak assignments (in Fig. 11) for $\mathrm{m} / \mathrm{z} 191$ (I) and $\mathrm{m} / \mathrm{z} 217$ (II) fragmentograms of saturated hydrocarbons.

\begin{tabular}{|c|c|c|c|c|c|}
\hline \multicolumn{3}{|c|}{$m / z 191$ (I) } & \multicolumn{3}{|c|}{ m/z 217 (II) } \\
\hline Label & Compound & Abbr. & Label & Compound & Abbr. \\
\hline 1 & $\mathrm{C}_{19}$ tricyclic terpane & $\mathrm{C}_{19} \mathrm{~T}$ & A & $\mathrm{C}_{22}$ homopregnane & $\mathrm{C}_{22} \mathrm{H}$ \\
\hline 2 & $\mathrm{C}_{20}$ tricyclic terpane & $\mathrm{C}_{20} \mathrm{~T}$ & B & $\mathrm{C}_{27} 13 \beta(\mathrm{H}), 17 \alpha(\mathrm{H})(20 \mathrm{~S})$-diasterane & $\mathrm{C}_{27} \beta \alpha 20 \mathrm{~S}$ \\
\hline 3 & $\mathrm{C}_{21}$ tricyclic terpane & $\mathrm{C}_{21} \mathrm{~T}$ & $\mathrm{C}$ & $\mathrm{C}_{27} 13 \beta(\mathrm{H}), 17 \alpha(\mathrm{H})(20 \mathrm{R})$-diasterane & $\mathrm{C}_{27} \beta \alpha 20 \mathrm{R}$ \\
\hline 4 & $\mathrm{C}_{22}$ tricyclic terpane & $\mathrm{C}_{22} \mathrm{~T}$ & $\mathrm{D}$ & $\mathrm{C}_{27} 13 \alpha(\mathrm{H}), 17 \beta(\mathrm{H})(20 \mathrm{~S})$-diasterane & $\mathrm{C}_{27} \alpha \beta 20 \mathrm{~S}$ \\
\hline 5 & $\mathrm{C}_{23}$ tricyclic terpane & $\mathrm{C}_{23} \mathrm{~T}$ & $\mathrm{E}$ & $\mathrm{C}_{27} 13 \alpha(\mathrm{H}), 17 \beta(\mathrm{H})(20 \mathrm{R})$-diasterane & $\mathrm{C}_{27} \alpha \beta 20 \mathrm{R}$ \\
\hline 6 & $\mathrm{C}_{24}$ tricyclic terpane & $\mathrm{C}_{24} \mathrm{~T}$ & $\mathrm{~F}$ & $\mathrm{C}_{28} 13 \beta(\mathrm{H}), 17 \alpha(\mathrm{H})(20 \mathrm{~S})$-diasterane & $\mathrm{C}_{28} \beta \alpha 20 \mathrm{~S}$ \\
\hline 7 & $\mathrm{C}_{25}$ tricyclic terpane & $\mathrm{C}_{25} \mathrm{~T}$ & G & $\mathrm{C}_{28} 13 \beta(\mathrm{H}), 17 \alpha(\mathrm{H})(20 \mathrm{R})$-diasterane & $\mathrm{C}_{28} \beta \alpha 20 \mathrm{R}$ \\
\hline 8 & $\mathrm{C}_{24}$ tetracyclic terpane & $\mathrm{C}_{24} \mathrm{Te}$ & $\mathrm{H}$ & $\mathrm{C}_{27} 5 \alpha(\mathrm{H}), 14 \alpha(\mathrm{H}), 17 \alpha(\mathrm{H})(20 \mathrm{~S})$-sterane & $\mathrm{C}_{27} \alpha \alpha \alpha 20 \mathrm{~S}$ \\
\hline 9 & $\mathrm{C}_{26}$ tricyclic terpane & $\mathrm{C}_{26} \mathrm{~T}$ & I & $\mathrm{C}_{27} 5 \alpha(\mathrm{H}), 14 \beta(\mathrm{H}), 17 \beta(\mathrm{H})(20 \mathrm{R})$-sterane & $\mathrm{C}_{27} \alpha \beta \beta 20 \mathrm{R}$ \\
\hline Ts & $\mathrm{C}_{27} 18 \alpha(\mathrm{H})-22,29,30$-trisnorneohopane & Ts & $\mathrm{J}$ & $\mathrm{C}_{27} 5 \alpha(\mathrm{H}), 14 \beta(\mathrm{H}), 17 \beta(\mathrm{H})(20 \mathrm{~S})$-sterane & $\mathrm{C}_{27} \alpha \beta \beta 20 \mathrm{~S}$ \\
\hline $\operatorname{Tm}$ & $\mathrm{C}_{27} 17 \alpha(\mathrm{H})-22,29,30$-trisnorhopane & $\mathrm{Tm}$ & $\mathrm{K}$ & $\mathrm{C}_{27} 5 \alpha(\mathrm{H}), 14 \alpha(\mathrm{H}), 17 \alpha(\mathrm{H})(20 \mathrm{R})$-sterane & $\mathrm{C}_{27} \alpha \alpha \alpha 20 \mathrm{R}$ \\
\hline 10 & $\mathrm{C}_{29} 17 \alpha(\mathrm{H}), 21 \beta(\mathrm{H})$-norhopane & $\mathrm{C}_{29} \mathrm{~N}$ & $\mathrm{~L}$ & $\mathrm{C}_{29} 13 \beta(\mathrm{H}), 17 \alpha(\mathrm{H})(20 \mathrm{R})$-diasterane & $\mathrm{C}_{29} \beta \alpha 20 \mathrm{R}$ \\
\hline 11 & $\mathrm{C}_{29} 18 \alpha(\mathrm{H})$-30-norneohopane & $\mathrm{C}_{29} \mathrm{Ts}$ & M & $\mathrm{C}_{29} 13 \beta(\mathrm{H}), 17 \alpha(\mathrm{H})(20 \mathrm{~S})$-diasterane & $\mathrm{C}_{29} \beta \alpha 20 \mathrm{~S}$ \\
\hline 12 & $\mathrm{C}_{29} 17 \beta(\mathrm{H}), 21 \alpha(\mathrm{H})$-hopane (normoretane) & $\mathrm{C}_{29} \mathrm{H}$ & $\mathrm{N}$ & $\mathrm{C}_{28} 5 \alpha(\mathrm{H}), 14 \alpha(\mathrm{H}), 17 \alpha(\mathrm{H})(20 \mathrm{~S})$-sterane & $\mathrm{C}_{28} \alpha \alpha \alpha 20 \mathrm{~S}$ \\
\hline 13 & $\mathrm{C}_{30} 17 \alpha(\mathrm{H}), 21 \beta(\mathrm{H})$-hopane & $\mathrm{C}_{30} \mathrm{H}$ & $\mathrm{O}$ & $\mathrm{C}_{28} 5 \alpha(\mathrm{H}), 14 \beta(\mathrm{H}), 17 \beta(\mathrm{H})(20 \mathrm{R})$-sterane & $\mathrm{C}_{28} \alpha \beta \beta 20 \mathrm{R}$ \\
\hline 14 & $\mathrm{C}_{30} 17 \beta(\mathrm{H}), 21 \alpha(\mathrm{H})$-hopane (moretane) & $\mathrm{C}_{30} \mathrm{M}$ & $\mathrm{P}$ & $\mathrm{C}_{28} 5 \alpha(\mathrm{H}), 14 \beta(\mathrm{H}), 17 \beta(\mathrm{H})(20 \mathrm{~S})$-sterane & $\mathrm{C}_{28} \alpha \beta \beta 20 \mathrm{~S}$ \\
\hline 15 & $\mathrm{C}_{31} 17 \alpha(\mathrm{H}), 21 \beta(\mathrm{H})(22 \mathrm{~S}, 22 \mathrm{R})$-homohopanes & $\mathrm{C}_{31}(\mathrm{~S}+\mathrm{R})$ & Q & $\mathrm{C}_{28} 5 \alpha(\mathrm{H}), 14 \alpha(\mathrm{H}), 17 \alpha(\mathrm{H})(20 \mathrm{R})$-sterane & $\mathrm{C}_{28} \alpha \alpha \alpha 20 \mathrm{R}$ \\
\hline 16 & Gammacerane & $\mathrm{C}_{30} \mathrm{G}$ & $\mathrm{R}$ & $\mathrm{C}_{29} 5 \alpha(\mathrm{H}), 14 \alpha(\mathrm{H}), 17 \alpha(\mathrm{H})(20 \mathrm{~S})$-sterane & $\mathrm{C}_{29} \alpha \alpha \alpha 20 \mathrm{~S}$ \\
\hline 17 & $\mathrm{C}_{32} 17 \alpha(\mathrm{H}), 21 \beta(\mathrm{H})(22 \mathrm{~S}, 22 \mathrm{R})$-homohopanes & $\mathrm{C}_{32}(\mathrm{~S}+\mathrm{R})$ & $S$ & $\mathrm{C}_{29} 5 \alpha(\mathrm{H}), 14 \beta(\mathrm{H}), 17 \beta(\mathrm{H})(20 \mathrm{R})$-sterane & $\mathrm{C}_{29} \alpha \beta \beta 20 \mathrm{R}$ \\
\hline 18 & $\mathrm{C}_{33} 17 \alpha(\mathrm{H}), 21 \beta(\mathrm{H})(22 \mathrm{~S}, 22 \mathrm{R})$-homohopanes & $\mathrm{C}_{33}(\mathrm{~S}+\mathrm{R})$ & $\mathrm{T}$ & $\mathrm{C}_{29} 5 \alpha(\mathrm{H}), 14 \beta(\mathrm{H}), 17 \beta(\mathrm{H})(20 \mathrm{~S})$-sterane & $\mathrm{C}_{29} 2 \alpha \beta \beta 20 \mathrm{~S}$ \\
\hline 19 & $\mathrm{C}_{34} 17 \alpha(\mathrm{H}), 21 \beta(\mathrm{H})(22 \mathrm{~S}, 22 \mathrm{R})$-homohopanes & $\mathrm{C}_{34}(\mathrm{~S}+\mathrm{R})$ & $\mathrm{U}$ & $\mathrm{C}_{29} 5 \alpha(\mathrm{H}), 14 \alpha(\mathrm{H}), 17 \alpha(\mathrm{H})(20 \mathrm{R})$-sterane & $\mathrm{C}_{29} 9 \alpha \alpha \alpha 20 \mathrm{R}$ \\
\hline
\end{tabular}




\section{Table 4}

Selected biomarker data for saturated hydrocarbons from the Eocene lacustrine oil shale extracts.

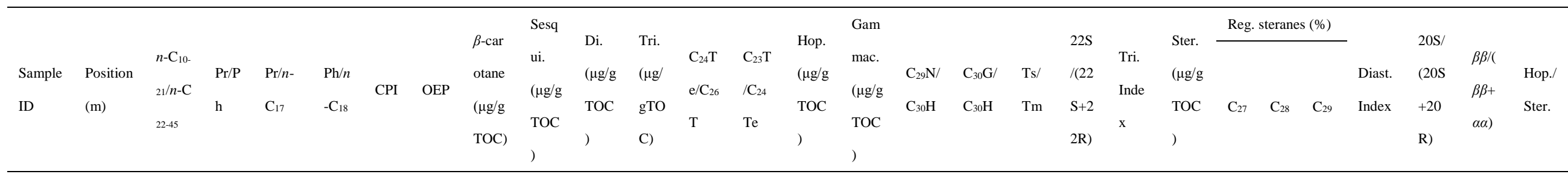

\begin{tabular}{|c|c|c|c|c|c|c|c|c|c|c|c|c|c|c|c|c|c|c|c|c|c|c|c|c|c|c|c|c|}
\hline \multicolumn{29}{|c|}{ Jijuntun Formation — ROSU } \\
\hline X78-1 & 159.3 & 0.49 & 1.46 & 0.82 & 0.65 & 1.55 & 1.73 & 1.37 & 7 & nd & 11 & 0.28 & 1.85 & 307 & 1.75 & 0.60 & 0.021 & 0.43 & 0.43 & 1.17 & 48 & 26 & 28 & 46 & 7.16 & 0.12 & 0.21 & 6.56 \\
\hline $\mathrm{X} 67-1$ & 140.2 & 0.27 & 1.79 & 2.73 & 1.72 & 1.76 & 1.87 & nd & 13 & 9 & 25 & 0.26 & 1.63 & 452 & 1.36 & 0.68 & 0.021 & 0.43 & 0.45 & 1.23 & 59 & 29 & 24 & 47 & 16.34 & 0.15 & 0.30 & 10.14 \\
\hline X63-1 & 133.6 & 0.58 & 1.90 & 1.27 & 1.31 & 1.16 & 2.23 & nd & 26 & 13 & 17 & 0.24 & 1.49 & 866 & 1.20 & 0.70 & 0.019 & 0.35 & 0.52 & 1.15 & 97 & 31 & 19 & 50 & 10.18 & 0.20 & 0.25 & 9.34 \\
\hline X59-1 & 124.9 & 0.38 & 1.56 & 1.53 & 1.81 & 1.38 & 1.65 & nd & 14 & 47 & 21 & 0.25 & 1.72 & 641 & 1.00 & 0.65 & 0.018 & 0.39 & 0.44 & 1.20 & 83 & 35 & 20 & 45 & 20.34 & 0.24 & 0.27 & 7.69 \\
\hline X52-1 & 110.4 & 0.17 & 2.08 & 9.44 & 3.27 & 1.77 & 1.81 & nd & 19 & nd & 33 & 0.22 & 1.78 & 622 & 0.89 & 0.77 & 0.016 & 0.41 & 0.47 & 1.19 & 79 & 39 & 16 & 45 & 17.69 & 0.14 & 0.29 & 8.11 \\
\hline X42-1 & 90.5 & 0.10 & 1.53 & 18.21 & 8.00 & 1.66 & 1.75 & nd & 10 & 25 & 19 & 0.28 & 1.99 & 523 & 1.05 & 0.82 & 0.018 & 0.33 & 0.51 & 1.06 & 39 & 39 & 17 & 44 & 9.19 & 0.17 & 0.29 & 14.54 \\
\hline X36-1 & 80.7 & 0.51 & 1.87 & 1.17 & 0.67 & 1.55 & 1.61 & nd & 22 & 37 & 19 & 0.24 & 2.00 & 467 & 0.68 & 0.69 & 0.014 & 0.40 & 0.53 & 0.53 & 39 & 34 & 20 & 47 & 24.81 & 0.47 & 0.32 & 11.70 \\
\hline \multicolumn{29}{|c|}{ Jijuntun Formation — LOSU } \\
\hline X35-2 & 74.0 & 0.21 & 2.98 & 1.91 & 0.53 & 1.90 & 2.14 & nd & 46 & 53 & 26 & 0.12 & 3.56 & 132 & 0.21 & 0.56 & 0.006 & 0.23 & 0.49 & 0.84 & 13 & 33 & 19 & 48 & 55.82 & 0.23 & 0.85 & 10.07 \\
\hline X30-1 & 63.5 & 0.55 & 2.91 & 2.20 & 0.86 & 1.79 & 2.02 & nd & 64 & 72 & 28 & 0.28 & 3.16 & 100 & 0.22 & 0.73 & 0.007 & 0.17 & 0.50 & 0.77 & 8 & 24 & 26 & 49 & 60.14 & 0.45 & 0.63 & 12.58 \\
\hline $\mathrm{X} 22-1$ & 47.5 & 0.54 & 4.51 & 4.01 & 0.92 & 1.85 & 2.04 & nd & 108 & 376 & 32 & 0.05 & 4.78 & 207 & 0.15 & 0.87 & 0.005 & 0.05 & 0.49 & 0.71 & 17 & 20 & 27 & 53 & 79.37 & 0.39 & 0.41 & 10.99 \\
\hline X11-2 & 29.6 & 0.33 & 3.09 & 5.05 & 1.74 & 1.87 & 2.42 & nd & 213 & 291 & 40 & 0.20 & 2.09 & 198 & 0.12 & 0.94 & 0.004 & 0.05 & 0.59 & 0.61 & 9 & 21 & 24 & 55 & 48.60 & 0.35 & 0.38 & 21.68 \\
\hline
\end{tabular}

Position $=$ meters from profile base $; \mathrm{Pr}=$ pristane $; \mathrm{Ph}=$ phytane $; \mathrm{CPI}=$ carbon preference index $;$ OEP $=$ odd-even preference $;$ Sesqui. $=$ sesquiterpenoids $;$ Di. $=$ diterpenoids;

Tri. = triterpenoids; Hop. = hopanes; Gammac. = gammacerane; $\mathrm{C}_{30} \mathrm{G} / \mathrm{C}_{30} \mathrm{H}($ Gammacerane index $)=$ gammacerane/C $\mathrm{C}_{30} \quad 17 \alpha(\mathrm{H}), 21 \beta(\mathrm{H})$-hopane; $\mathrm{Ts}=\mathrm{C}_{27}$ 
$18 \alpha(\mathrm{H})-22,29,30$-trisnorneohopane; $\mathrm{Tm}=\mathrm{C}_{27} 17 \alpha(\mathrm{H})-22,29,30$-trisnorhopane; $22 \mathrm{~S} /(22 \mathrm{~S}+22 \mathrm{R})=\left[\mathrm{C}_{31-33} 22 \mathrm{~S} 17 \alpha(\mathrm{H}), 21 \beta(\mathrm{H})-\right.$ homohopanes $] /\left[\mathrm{C}_{31-33}(22 \mathrm{~S}+22 \mathrm{R})\right.$ $17 \alpha(\mathrm{H}), 21 \beta(\mathrm{H})$-homohopanes $]$; Tri. Index $=100 *\left[\mathrm{C}_{23}\right.$ tricyclic terpane/ $\mathrm{C}_{30} 17 \alpha(\mathrm{H}), 21 \beta(\mathrm{H})$-hopane $] ;$ Ster. $=$ steranes; $\mathrm{C}_{27}=100 *\left[\mathrm{C}_{27} /\left(\mathrm{C}_{27}+\mathrm{C}_{28}+\mathrm{C}_{29}\right) 5 \alpha(\mathrm{H}), 14 \alpha(\mathrm{H}), 17 \alpha(\mathrm{H})\right.$ $(20 \mathrm{~S}+20 \mathrm{R})$-steranes] $\left(\mathrm{C}_{28}\right.$ and $\mathrm{C}_{29}$ in regular steranes obtained through similar calculation $) ;$ Diast. Index $=100 *\left[\mathrm{C}_{27}(20 \mathrm{R}+20 \mathrm{~S}) 13 \beta(\mathrm{H}), 17 \alpha(\mathrm{H})-\mathrm{diasteranes} / \mathrm{C}_{27}(20 \mathrm{~S}+20 \mathrm{R})\right.$ $5 \alpha(\mathrm{H}), 14 \alpha(\mathrm{H}), 17 \alpha(\mathrm{H})$-steranes $] ; \quad 20 \mathrm{~S} /(20 \mathrm{~S}+20 \mathrm{R})=[20 \mathrm{~S} /(20 \mathrm{~S}+20 \mathrm{R})] \quad \mathrm{C}_{29} \quad 5 \alpha(\mathrm{H}), 14 \alpha(\mathrm{H}), 17 \alpha(\mathrm{H})-\mathrm{steranes} ; \quad \beta \beta /(\beta \beta+\alpha \alpha)=\left[\mathrm{C}_{27-29} \quad(20 \mathrm{~S}+20 \mathrm{R})\right.$ $5 \alpha(\mathrm{H}), 14 \beta(\mathrm{H}), 17 \beta(\mathrm{H})$-steranes $] /\left\{\left[\mathrm{C}_{27-29}(20 \mathrm{~S}+20 \mathrm{R}) 5 \alpha(\mathrm{H}), 14 \beta(\mathrm{H}), 17 \beta(\mathrm{H})\right.\right.$-steranes $]+\left[\mathrm{C}_{27-29}(20 \mathrm{~S}+20 \mathrm{R}) 5 \alpha(\mathrm{H}), 14 \alpha(\mathrm{H}), 17 \alpha(\mathrm{H})\right.$-steranes $\left.]\right\} ;$ nd $=$ not detected. 
Fig.1. (a) Location (insert map) and tectonic frameworks of NE China (modified after Wu et al., 2011), (b) main Meso-Cenozoic basins around the bifurcation of the northern Tanlu Fault into the Yilan-Yitong and Dun-Mi faults (modified after Chen et al., 2003), and (c) sketch geologic map of the Fushun Basin (modified after Wu et al., 2000; Meng et al., 2012; Strobl et al., 2014a).

Fig.2. Simplified north-south tectonic cross-section (see Fig. 1c for location) showing the faults movement and stratigraphic contact relationships (modified after Liu et al., 2009; Xu et al., 2012).

Fig.3. More detailed east-west lithostratigraphic cross-section (see Fig. 1c for location). All profiles occured in the cross-section were horizontally correlated to depositional onset of the Xilutian Formation to mainly illustrate infilling of the Jijuntun (oil shale-bearing) and Guchengzi (coal-bearing) formations (modified after Xu et al., 2012, 2013).

Fig.4. Measured profile showing basic depositional facies, identified cycles and sampling positions in this study (see Fig.1c for location). The measured geomagnetic polarities (data from Zhao et al., 1992) combining with a volcanic K-Ar age (52.09 \pm 0.46 Ma in the middle Guchengzi Formation; Wang et al., 1989) in the Fushun Basin were calibrated to the GPTS (geomagnetic polarity time scale; Cande and Kent, 1992, 1995) to obtain a time stratigraphic profile. 
Fig.5. Outcrop photographs for the Eocene lacustrine oil shale deposits. (a) Exposure of the Jijuntun Formation subdivided into the lower lean oil shale unit (LOSU) and the upper rich oil shale unit (ROSU) (dashed line), also showing parallel conformities (solid line) with the underlying Guchengzi Formation and overlying Xilutian Formation, respectively (truck for scale). (b) Depositional cycles in the LOSU indicated by color and lithologic variations (power bar for scale). Massive oil shales with (c) very thin coal layes $(<2 \mathrm{~cm})$ and (d) silty lenses and/or intraclasts in the LOSU (coin for scale). (e-g) Leaf fossils and (h) gastropods preserved in non-laminated oil shales in the LOSU (coin for scale). (i) Depositional cycles in the ROSU indicated by color and lithologic variations (person for scale). Laminated oil shales with $(j)$ fine $(<2 \mathrm{~mm})$ and $(k)$ coarse laminations $(\geq 2 \mathrm{~mm})$ in the ROSU (coin and camera cover for scale). (l) Fish fossil preserved in the fine-laminated oil shale in the ROSU. See Fig. 4 for explanation of lithologic symbols.

Fig.6. Vertical variations in trace element concentrations for the Eocene lacustrine oil shale samples studied. See Fig. 4 for explanation of lithologic symbols.

Fig.7. Concentration coefficients $(\mathrm{CC}$, the ratios of trace element concentrations in oil shale samples investigated vs. averages in world black shales; e.g. Dai et al., 2015) for the studied trace elements, according to subdivided oil shale types. Data of 
average trace element concentrations in world black shales are from Ketris and Yudovich (2009).

Fig.8. Vertical variations in isolated kerogen elements, Rock-Eval pyrolysis results and extractable organic matter (EOM) compositions for the Eocene lacustrine oil shale samples studied. See Fig. 4 for explanation of lithologic symbols.

Fig.9. (a) Van Krevelen elemental plot (after Tissot and Welte, 1984), (b) Rock-Eval HI vs. OI diagram (after Peters, 1986), and (c) $\mathrm{S}_{2}$ vs. TOC plot (showing true $\mathrm{HI}$ values of 394 and $635 \mathrm{mg} \mathrm{HC/g}$ TOC, respectively; after Langford and Blanc-Valleron, 1990) for the Eocene lacustrine oil shale samples studied.

Fig.10. Total ion chromatograms (TICs) of saturated hydrocarbons for the representative Eocene lacustrine oil shale samples studied. Labels on peaks refer to carbon-number of $n$-alkanes $\left(n-\mathrm{C}_{15}, n-\mathrm{C}_{20}, n-\mathrm{C}_{25}, n-\mathrm{C}_{30}\right.$ and $\left.n-\mathrm{C}_{35}\right)$, pristane (Pr), phytane $(\mathrm{Ph}), \mathrm{C}_{29} 17 \alpha(\mathrm{H}), 21 \beta(\mathrm{H})$-norhopane $(\mathrm{H} 29)$, and $\beta$-carotane $(\beta)$.

Fig.11. (a) $\mathrm{m} / \mathrm{z} 191$ (hopanes) and (b) $\mathrm{m} / \mathrm{z} 217$ (steranes) chromatograms of saturated hydrocarbons for the representative Eocene lacustrine oil shale samples studied (see Table 3 for peak identifications).

Fig.12. Vertical variations in biomarker ratios for the Eocene lacustrine oil shale extracts. See Fig. 4 for explanation of lithologic symbols. 
Fig.13. Diagrams related to depositional conditions of the Eocene lacustrine oil shale deposits. (a) Vanadium vs. Ni concentrations plot (after Galarraga et al., 2008; Akinlua et al., 2010) and (b) V/Cr vs. Ni/Co ratios plot showing redox conditions. (c) $\mathrm{C}_{27} /\left(\mathrm{C}_{27}+\mathrm{C}_{29}\right)$ regular steranes vs. $\mathrm{Pr} / \mathrm{Ph}$ ratios plot (after Waseda and Nishita, 1998; Zakir Hossain et al., 2009), (d) $\mathrm{Pr} / n-\mathrm{C}_{17}$ alkane vs. $\mathrm{Ph} / n-\mathrm{C}_{18}$ alkane ratios plot and (e) ternary diagram of $\mathrm{C}_{27}-\mathrm{C}_{28}-\mathrm{C}_{29}$ regular steranes (after Huang and Meinschein, 1979) showing depositional conditions and organic matter $(\mathrm{OM})$ source. (f) V/Ni vs. Sr/Ba ratios plot (after Adegoke et al., 2014) and (g) gammacerane index vs. Sr/Ba ratio plot (after Sarki Yandoka et al., 2015) showing water salinity and stratification. (h) $\mathrm{Ga} / \mathrm{Rb}$ vs. $\mathrm{Sr} / \mathrm{Cu}$ ratios plot (after Roy and Roser, 2013) showing paleoclimatic variations.

Fig.14. Plots of Mn concentrations vs. (a) TOC and (b) HI, and Mo concentrations vs. (c) TOC and (d) HI showing the correlations of enriched Mn and depleted Mo with OM in the Eocene lacustrine oil shale samples studied, respectively. 

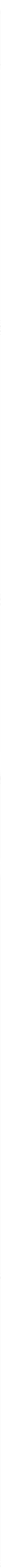


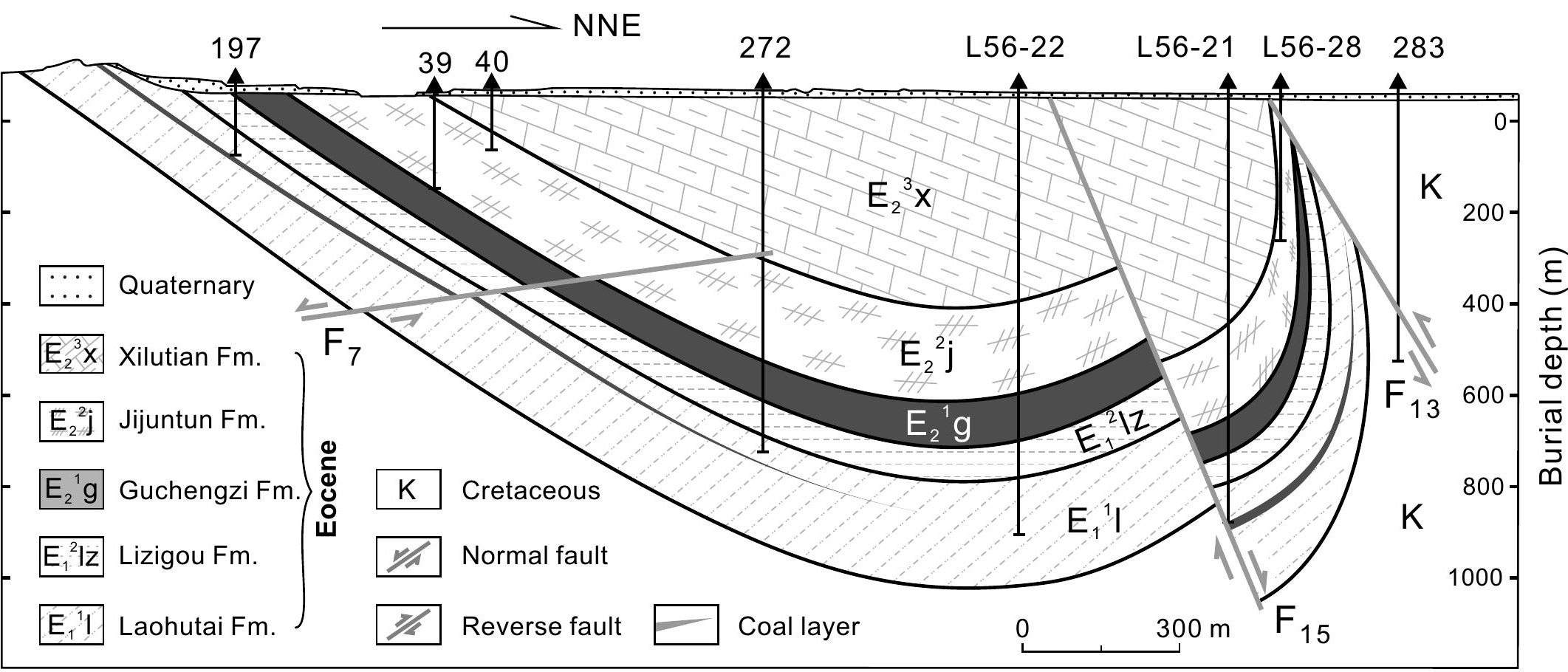




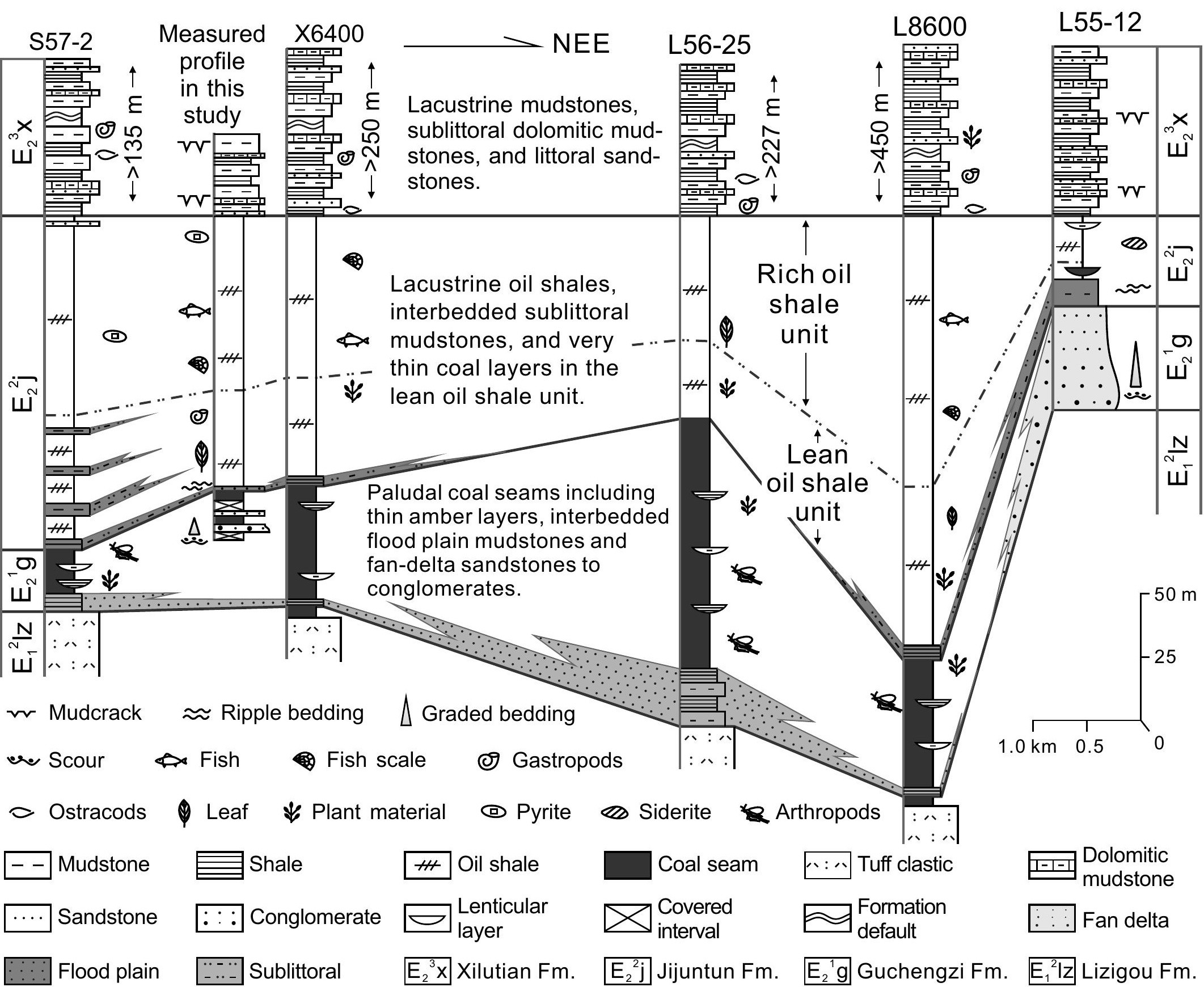




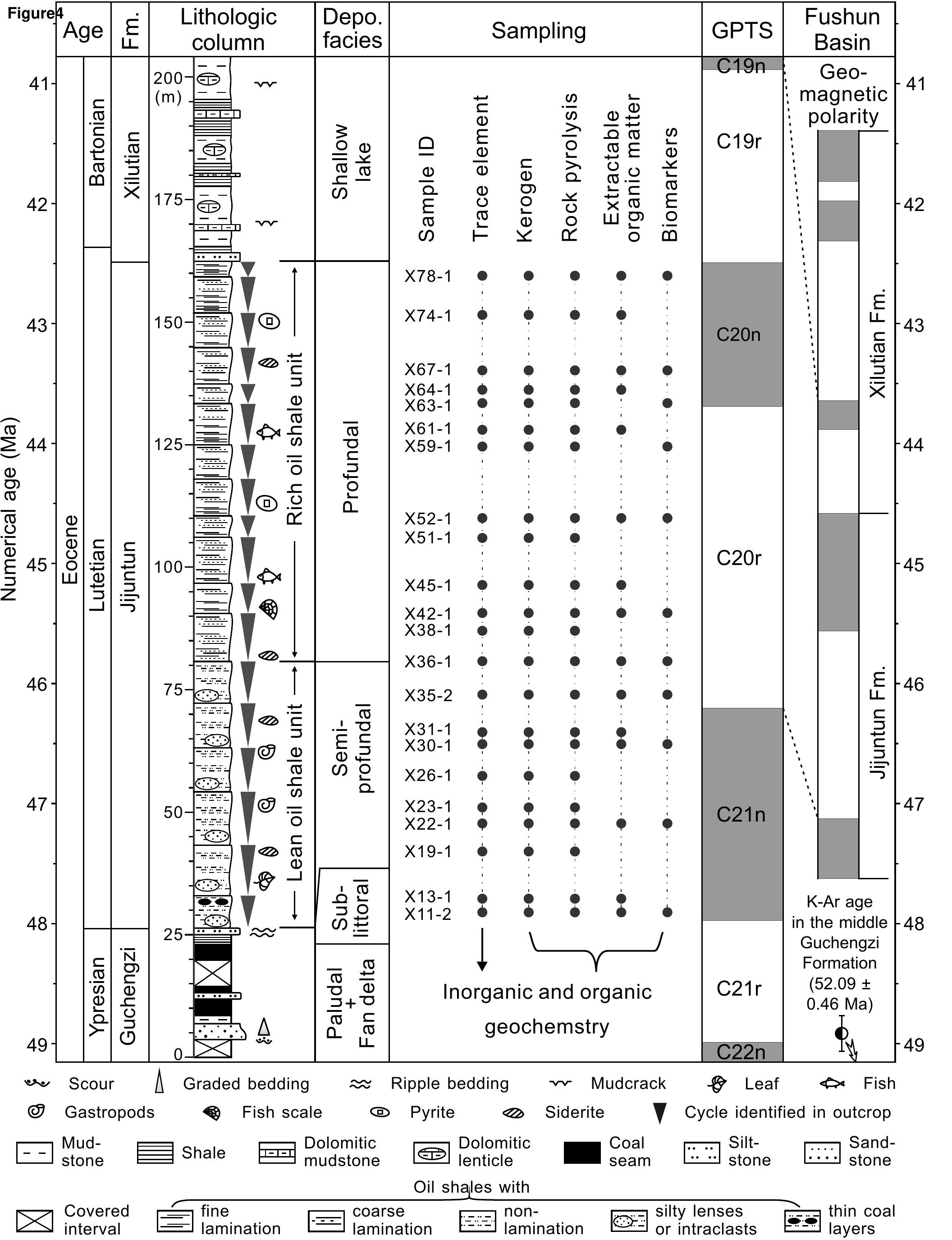


Click here to download high resolution image



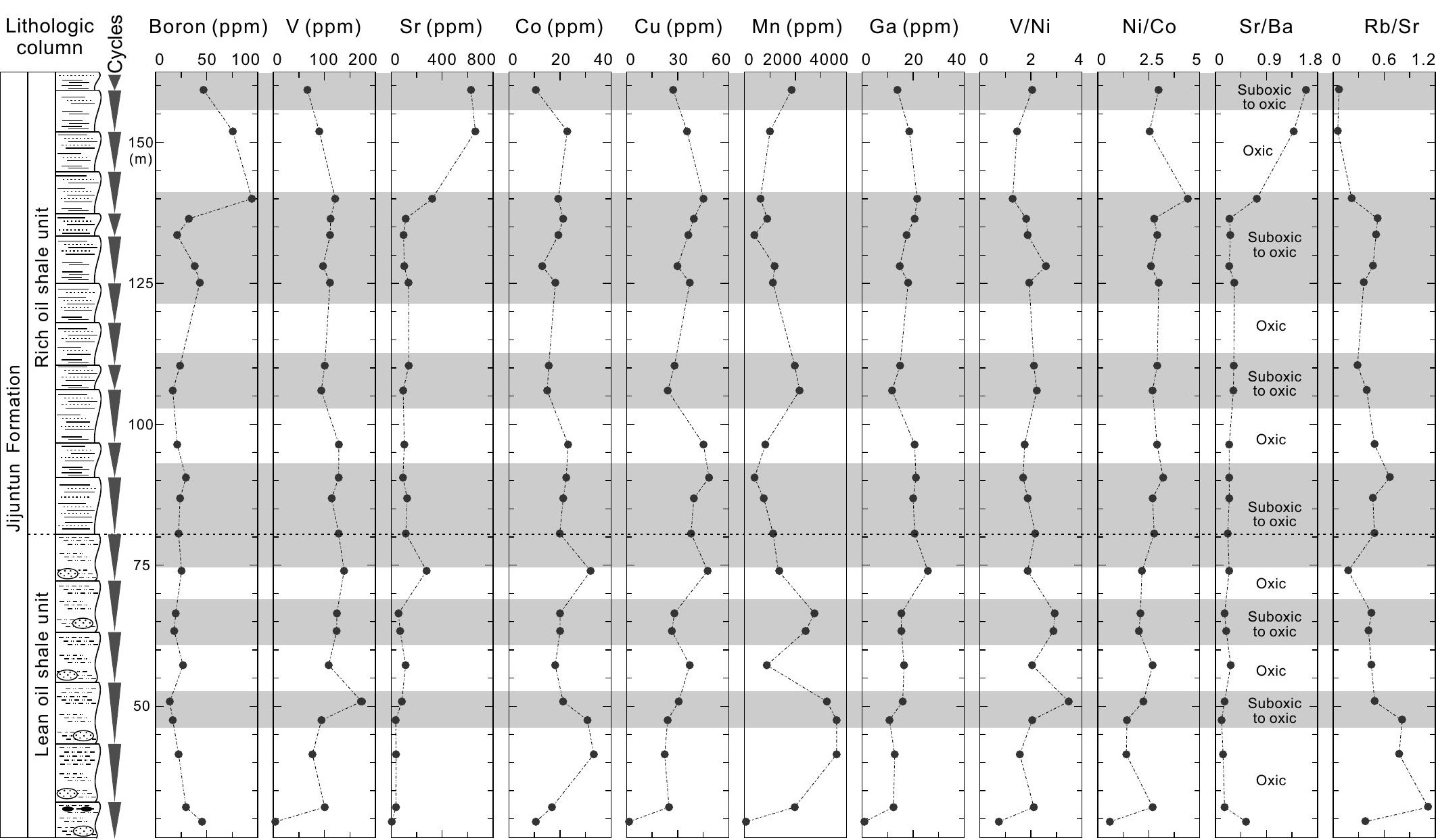




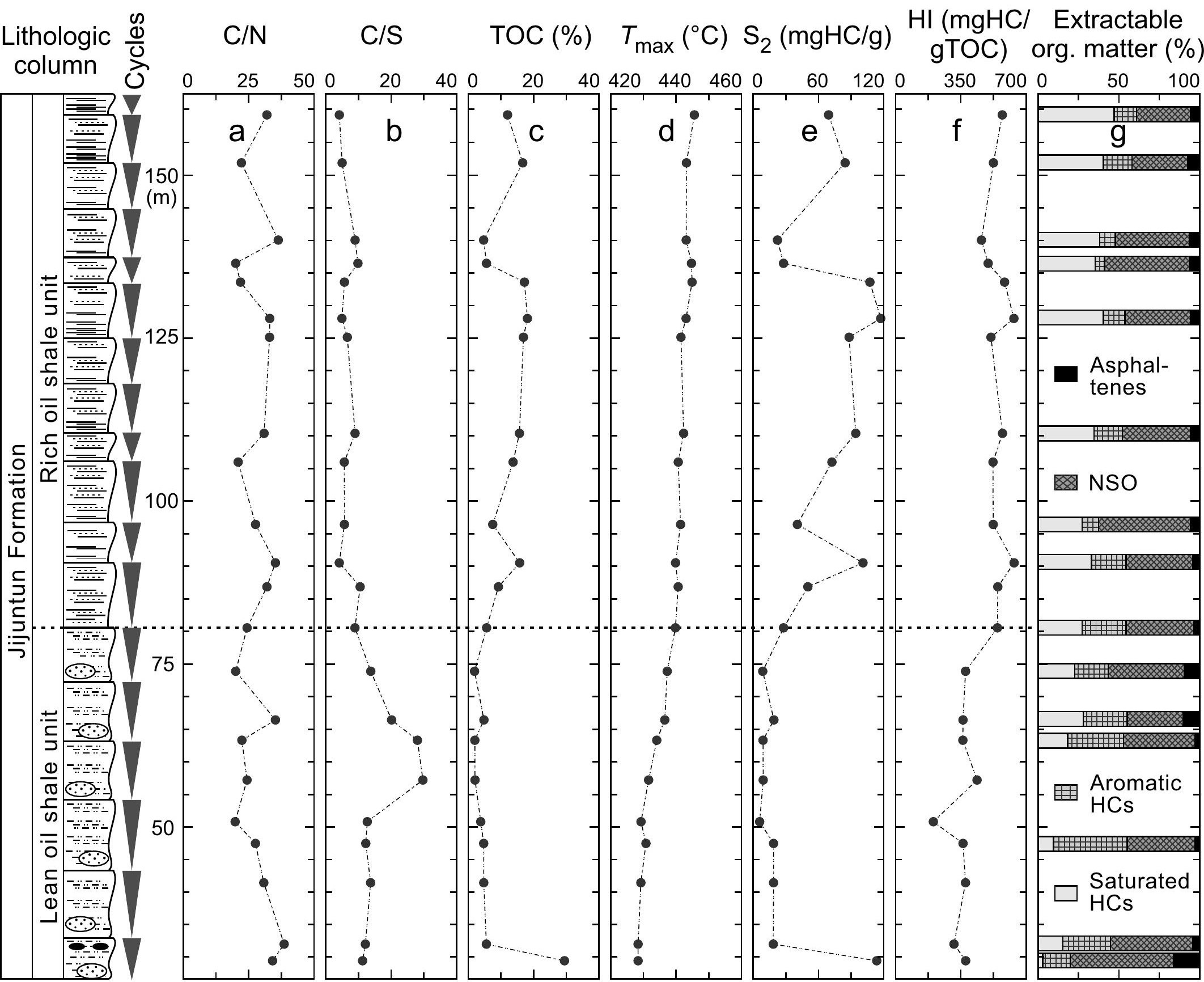



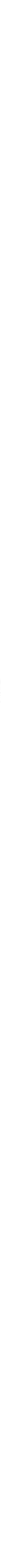


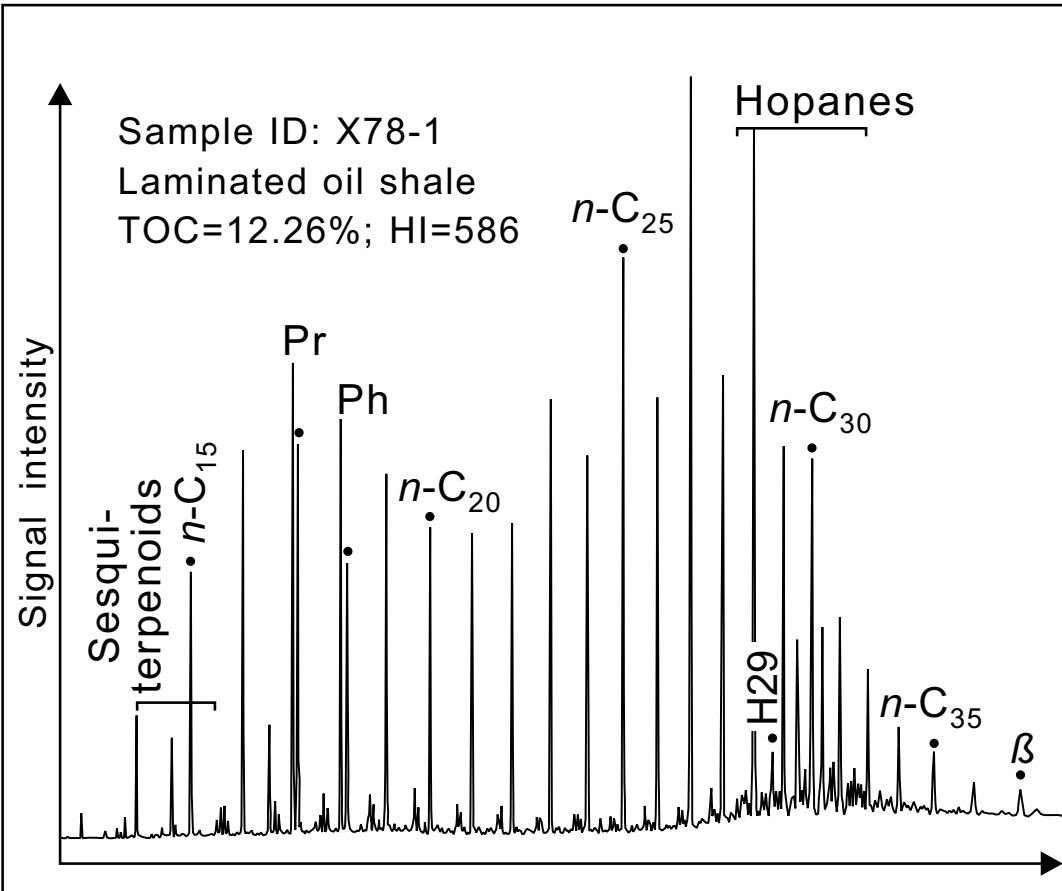

Retention time

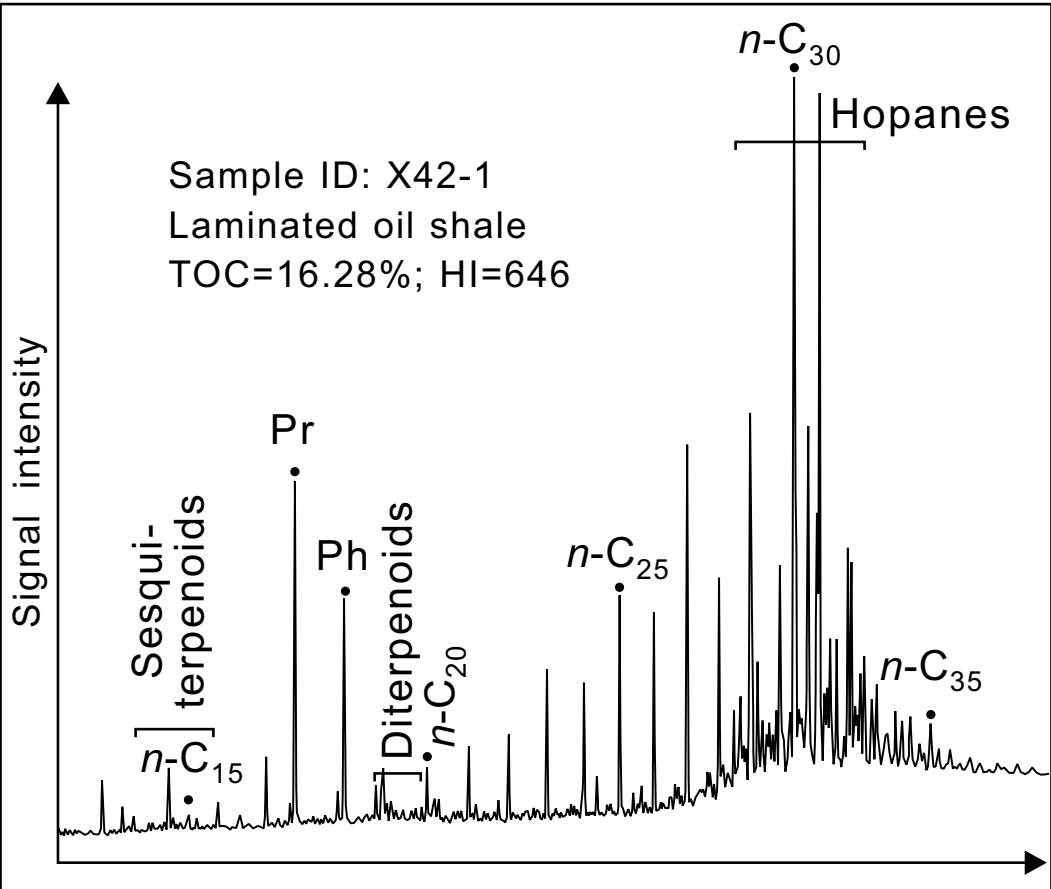

Retention time

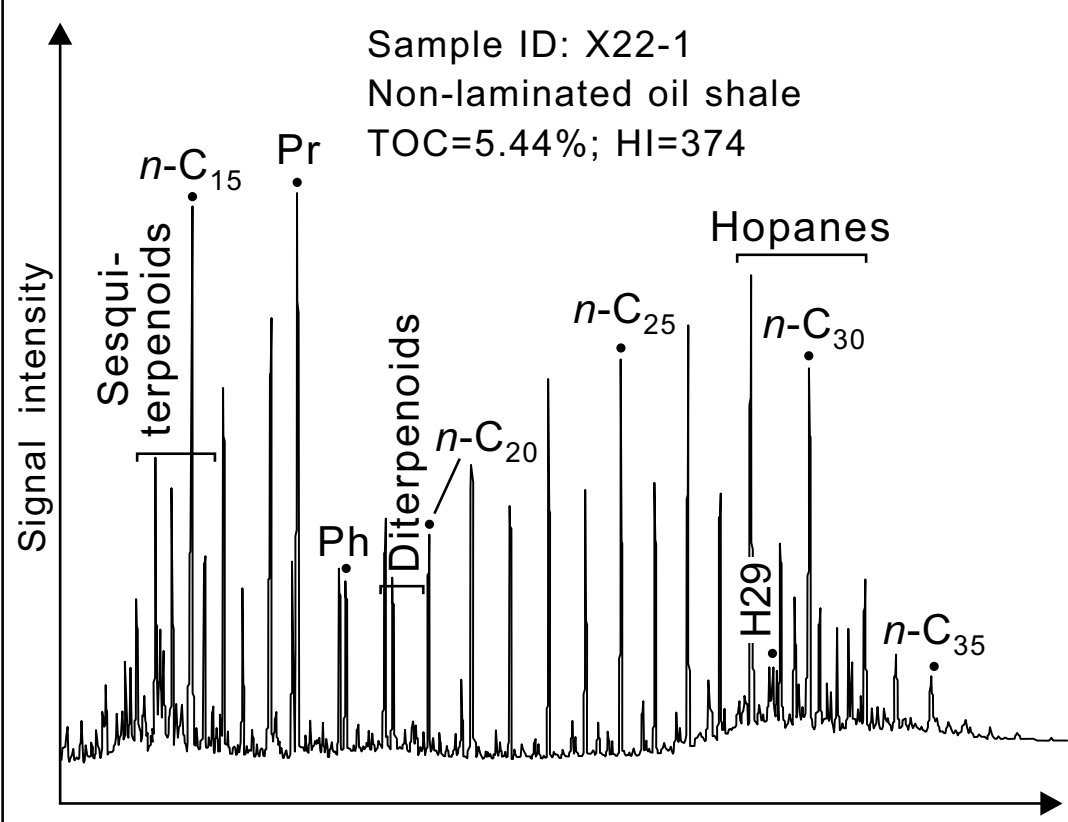

Retention time

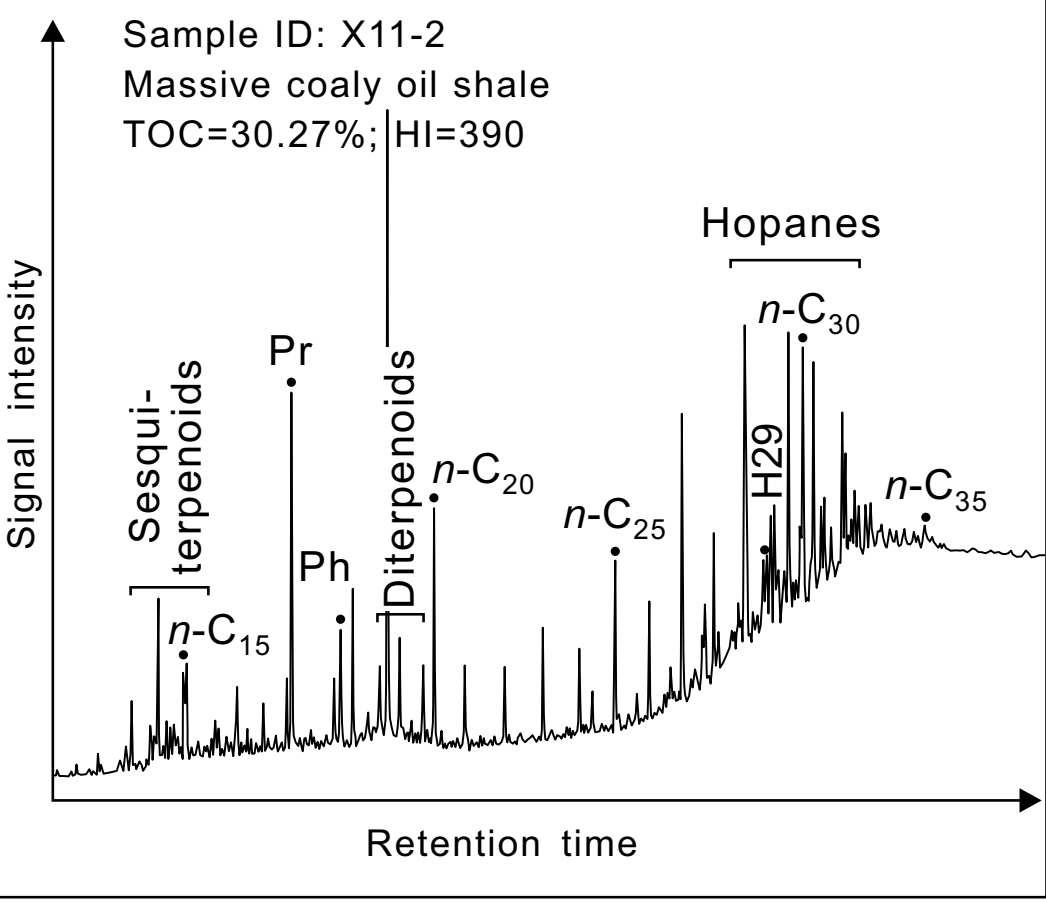




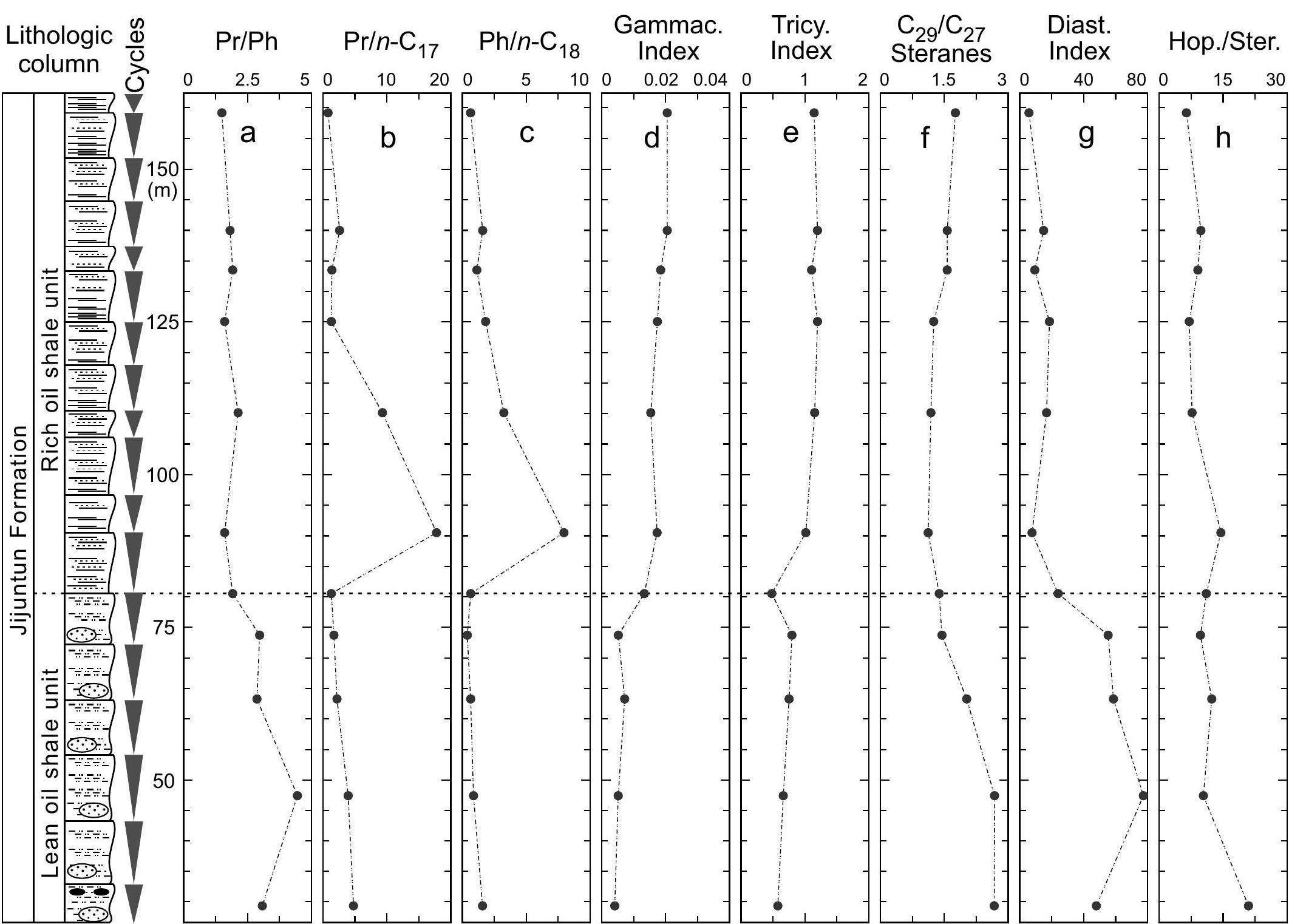



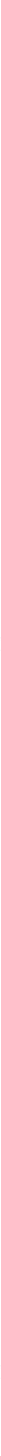

LOSU

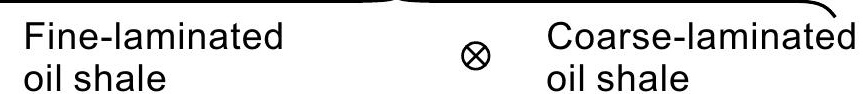

Non-laminated to massive oil shale 